\title{
Critical Nodes of Virus-Host Interaction Revealed Through an Integrated Network Analysis
}

Korbinian Bösl ${ }^{1,2}$, Aleksandr Ianevski ${ }^{2}$, Thoa T. Than ${ }^{3}$, Petter I. Andersen $^{2}$, Suvi Kuivanen ${ }^{4}$, Mona Teppor ${ }^{5}$, Eva Zusinaite ${ }^{5}$, Uga Dumpis $^{6}$, Astra Vitkauskiene ${ }^{7}$, Rebecca J. Cox ${ }^{8}$, Hannimari Kallio-Kokko ${ }^{9}$, Anders Bergqvist ${ }^{10}$, Tanel Tenson ${ }^{5}$, Valentyn Oksenych ${ }^{2}$, Magnar Bjørås ${ }^{2}$, Marit W. Anthonsen ${ }^{2}$, David Shum ${ }^{3}$, Mari Kaarb $\emptyset^{11}$, Olli Vapalahti1 ${ }^{12}$, Marc P. Windisch ${ }^{3}$, Giulio Superti-Furga ${ }^{13,14}$, Berend Snijder $^{15}$, Denis Kainov ${ }^{2,5}$, and Richard K. Kandasamy ${ }^{1,2,16}$

${ }^{1}$ Centre of Molecular Inflammation Research (CEMIR), Norwegian University of Science and Technology, Trondheim, Norway

${ }^{2}$ Department of Clinical and Molecular Medicine, Norwegian University of Science and Technology, Trondheim, Norway

${ }^{3}$ Institut Pasteur Korea, Gyeonggi-do, Republic of Korea

${ }^{4}$ Department of Virology, University of Helsinki, Helsinki, Finland

${ }^{5}$ Institute of Technology, University of Tartu, Tartu, Estonia

${ }^{6}$ Pauls Stradins Clinical University Hospital, Riga, Latvia

7 Department of Laboratory Medicine, Lithuanian University of Health Science, Kaunas, Lithuania

${ }^{8}$ Influenza Centre, Department of Clinical Science, University of Bergen, Bergen, Norway

${ }^{9}$ Department of Virology and Immunology, University of Helsinki, Helsinki University Hospital, Helsinki, Finland

${ }^{10}$ Department of Medical Sciences, Uppsala University, Uppsala, Sweden

${ }^{11}$ Department of Microbiology, Oslo University Hospital, Oslo, Norway

${ }^{12}$ Department of Veterinary Biosciences, University of Helsinki, Helsinki, Finland

${ }^{13}$ CeMM Research Center for Molecular Medicine of the Austrian Academy of Sciences, Vienna, Austria

${ }^{14}$ Center for Physiology and Pharmacology, Medical University of Vienna, Vienna, Austria

${ }^{15}$ Department of Biology, Institute of Molecular Systems Biology, ETH Zürich, Zürich, Switzerland

${ }^{16}$ Centre for Molecular Medicine Norway (NCMM), Nordic EMBL Partnership, University of Oslo and Oslo University Hospital, Oslo, Norway

${ }^{*}$ To whom correspondence should be addressed; E-mail: richard.k.kandasamy@ntnu.no 
Viruses are one of the major causes of various acute and chronic infectious diseases and thus a major contributor to the global burden of disease. Several studies have shown how viruses have evolved to hijack basic cellular pathways and evade innate immune response by modulating key host factors and signalling pathways. A collective view of these multiple studies could advance our understanding of viral evasion mechanisms and provide new therapeutic perspectives for the treatment of viral diseases. Here, we performed an integrative meta-analysis to elucidate the 17 different host-virus interactomes. Network and bioinformatics analyses showed how viruses with small genomes efficiently achieve the maximal effect by targeting multifunctional and highly connected host proteins with a high occurrence of disordered regions. We also identified the core cellular process subnetworks that are targeted by all the viruses. Integration with functional RNA interference (RNAi) datasets showed that a large proportion of the targets are required for viral replication. Furthermore, we performed an interactome-informed drug re-purposing screen and identified novel activities for broad-spectrum antiviral agents against hepatitis $\mathbf{C}$ virus and human metapneumovirus. Altogether, these orthogonal datasets could serve as a platform for hypothesis generation and follow-up studies to broaden our understanding of the viral evasion landscape.

\section{Introduction}

Viruses continue to be a major contributor to the global burden of disease through acute and chronic infections that cause substantial economic impact in addition to increased mortality and morbidity (Virgin et al. 2009). Despite the tremendous improvement in the understanding of the antiviral immune response and the availability of therapeutics, existing and emerging viral diseases are an ever-growing problem, particularly in developing countries. Development of antiviral resistance of viruses such as hepatitis $\mathrm{C}$ virus (HCV), influenza A virus (IAV), herpes simplex virus (HSV), human cytomegalovirus (HCMV) and human immunodeficiency virus (HIV) is a major concern (Irwin et al. 2016, Howard and Fletcher 2012, Bacon et al. 2003). One of the main reasons for increasing resistances is the accumulation of mutations in the viral genome caused by multiple factors including the polymerase infidelity (Sanjuan and Domingo-Calap 2016, Peck and Lauring 2018). Therefore, the World Health Organization (WHO) has urged for better control of viral diseases.

This has led to turning the focus on the host for therapeutic intervention, where targeting the host factors has been proven to be useful for restricting viral infections (Zumla et al. 2016, Kaufmann et al. 2018). Anti-CXCR4 and anti-CCR5 monoclonal antibodies are examples of successful host-directed therapies for combating HIV (Olson and Jacobson 2009, Carnec et al. 2005).

Viruses have evolved to evade the host antiviral response at various stages starting from viral sensing to antiviral pro-inflammatory responses (Bowie and Unterholzner 2008, Navratil et al. 2011, Garcia-Sastre 2017). Multiple studies attempted to understand global principles of the viral evasion employed by various viruses, including dengue virus (DENV), Ebola virus (EBOV), IAV and HIV (Pichlmair et al. 2012, Rozenblatt-Rosen et al. 2012, Jäger et al. 2011, Shah et al. 2018, Batra et al. 2018, Söderholm et al. 2016). Global systems-level approaches including functional RNAi screens, interactome mapping technologies such as affinity- 
purification mass spectrometry (AP-MS), quantitative proteomics and CRISPR/Cas9-based screens have provided unparalleled details and insights into the dynamics of host proteome in immune cells (Weekes et al. 2014, Nightingale et al. 2018, Kandasamy et al. 2016, Ersing et al. 2017), host-virus interactome (Pichlmair et al. 2012, Rozenblatt-Rosen et al. 2012, Jäger et al. 2011, Shapira et al. 2009, Konig et al. 2010), and also identified important host dependency factors of various viruses (Shapira et al. 2009, Zhang et al. 2016, Marceau et al. 2016). Meta-analyses of such high-dimensional datasets have been crucial for identifying novel host factors as drug targets such as UBR4 in IAV infection (Tripathi et al. 2015). Moreover, some of these factors represent drug targets for multiple viruses(Ianevski et al. 2018).

We hypothesized that combining a meta-analysis of host-virus protein-protein interactions of multiple viruses and functional RNAi screens would provide novel insights for developing broad-spectrum antiviral strategies. For this, we assembled a host-virus protein-protein interactome of 5781 host-virus interactions (hereafter referred to as 'hvPPI') covering 183 viral proteins from 17 different viruses and 2381 host proteins. We performed extensive bioinformatics and network analysis and integrated this dataset with genome-wide or druggable-genome RNAi screen data from published studies. This resulted in the assembly of critical nodes of viral evasion and identification of core cellular processes and druggable nodes that were verified by a drug re-purposing screen using broad-spectrum antivirals.

\section{Material \& Methods}

\section{Construction of hvPPI data, network analysis and data visualization}

Host-virus protein-protein interactions were downloaded from published studies (Pichlmair et al. 2012, Rozenblatt-Rosen et al. 2012, Jäger et al. 2011, Shapira et al. 2009, de Chassey et al. 2008, Khadka et al. 2011, Zhang et al. 2009, Vidal et al. 2011) which included a total of 183 viral proteins, 2381 host proteins and 5781 host-virus interactions. Protein identifiers were mapped to UniProt IDs. Human protein-protein interaction data was imported from BioGRID database (version 3.4.139, Stark et al. 2006) covering 215244 interactions. The network analysis was performed using in-house programs developed in $\mathrm{R}$ statistical environment (version 3.4.3, www.r-project.org) with the use of the packages SparseM (version 1.77), RBGL (version 1.52.0) and graph (version 1.54.0). Network visualization was performed in Cytoscape (version 3.6.1, Shannon et al. 2003). Network clusters/sub-networks were extracted using the Cytoscape plugin MCODE (version 1.5.1, Bader and Hogue 2003). Data visualization was performed in R statistical environment and Cytoscape.

\section{Gene-set enrichment, protein disorder and sub-cellular localization analysis}

We performed gene-set enrichment analysis using DAVID Bioinformatics Resources (version 6.8, Huang da et al. 2009). For all enrichment analysis, a p-value cutoff of $\leq 0.01$ was used as significant. Protein disorder analysis was performed using IUPred2A software. We used the offline version with protein sequences downloaded from UniProt. Statistical analysis of disordered region distribution was performed by Kolmogorov-Smirnov test in $\mathrm{R}$ statistical environment. Annotation of human proteins was mapped from UniProt ID to ENSEMBL using EnsDb.Hsapiens.v86. The index of subcellular localization of interaction partners of single viral proteins was calculated for all viral proteins with $\geq$ five host targets. Localization of host targets was mapped using COMPARTMENTS (Binder et al. 2014), filtered for a minimum evidence score of 3 in the knowledge channel, excluding non-experimental based 
localization predictions. Evidence for all protein was subsequently divided by the absolute number of host-targets per viral protein. Multiple sequence alignment was performed using Clustal X (version 2.0, Larkin et al. 2007).

\section{Integration of RNAi screens and drug-gene interaction data}

Genome-wide RNAi screen data for HCV (Tai et al. 2009) and HPV18 ( Smith et al. 2010, through GenomeRNAi database (Schmidt et al. 2013- GR00197), as well as druggable RNAi screen data for HPV16 (Aydin et al. 2014), VACV (Mercer et al. 2012) and SV40 (Snijder et al. 2012) were integrated in the existing network as Z-Scores. Drug-gene interaction data was downloaded from DGIdb. The identifiers were mapped to UniProt IDs and then compared with hvPPI.

\section{Drug re-purposing screen}

For the HMPV NL/1/00 screen, approximately $4 \times 10^{4}$ human retinal pigment epithelial (RPE) cells were seeded per well in 96-well plates. The cells were grown for $24 \mathrm{~h}$ in DMEM-F12 medium supplemented with $10 \% \mathrm{FBS}, 0.35 \% \mathrm{NaHCO}_{3}$, and $100 \mathrm{\mu g} / \mathrm{ml}$ streptomicine and 100 $\mathrm{IU} / \mathrm{ml}$ penicillin. The medium was replaced with virus growth medium (VGM) containing $0.2 \%$ bovine serum albumin (BSA), $2 \mathrm{mM}$ L-glutamine, $0.35 \% \mathrm{NaHCO}_{3}$, and $1 \mathrm{\mu g} / \mathrm{mL} \mathrm{L-1-}$ tosylamido-2-phenylethyl chloromethyl ketone-trypsin in DMEM-F12. HCV screen-associated cell culture conditions are described in Kim et al. (2016). The compounds were added to the cells in 3-fold dilutions at seven different concentrations starting from $50 \mu \mathrm{M}$. No compounds were added to the control wells. The cells were mock- or virus-infected at a multiplicity of infection (MOI) of one. After $48 \mathrm{~h}$ of infection, the medium was removed from the cells. To monitor cell viability, CellTiter-Glo reagent containing Firefly luciferase and luciferin was added $(30 \mu \mathrm{L}$ per well). This assay quantifies ATP, an indicator of metabolically active living cells. The luminescence was measured with a plate reader. To determine compound efficacy, HMPV NL/1/00-induced GFP expression was measured. The half-maximal cytotoxic concentration $\left(C C_{50}\right)$ and the half-maximal effective concentration $\left(E C_{50}\right)$ for each compound were calculated after non-linear regression analysis with a variable slope using GraphPad Prism software version 7.0a. The relative effectiveness of the drug was quantified as the selectivity index $\left(S I=\frac{C C_{50}}{E C_{50}}\right)$.

Cytotoxicity and antiviral activity of the compounds against GFP-expressing HCV in Huh-7.5 cells was determined as previously described (Kim et al. 2016). 


\section{Results}

\section{Assembly of host-virus protein-protein interactions}

To provide new and critical insights into viral evasion mechanisms we performed a comprehensive meta-analysis of the host-virus interaction landscape. We assembled the host-virus protein-protein interaction data ('hvPPI') from published studies (Fig. 1A) (Pichlmair et al. 2012, Rozenblatt-Rosen et al. 2012, Jäger et al. 2011, Shapira et al. 2009, de Chassey et al. 2008, Khadka et al. 2011, Zhang et al. 2009, Vidal et al. 2011). This dataset covered 17 different viruses including adeno-associated virus 5 (AAV5), dengue virus (DENV), Epstein-Barr virus (EBV), influenza A virus PR8 (IAV-PR8), influenza virus Udorn (IAV-Udorn), hepatitis $\mathrm{C}$ virus (HCV), human immunodeficiency virus 1 (HIV-1), human papilloma virus 5 (HPV5), human papilloma virus 6B (HPV6B), human papilloma virus 8 (HPV8), human papilloma virus 11 (HPV11), human papilloma virus 16 (HPV16), human papilloma virus 18 (HPV18), human papilloma virus 33 (HPV33), Merkel cell polyomavirus (MCPyV), Simian virus 40 (SV40) and Vaccinia virus (VACV). This dataset comprised of protein-protein interactions from two different types of experimental methods - affinity purification mass spectrometry (AP-MS) and yeast two-hybrid screens (Y2H). Altogether, this combined dataset includes 183 viral proteins, 2381 host proteins and 5781 protein-protein interactions (Fig. 1B and Fig. S1). Many interactome networks including yeast and human are scale-free networks, where a large portion of the nodes (e.g. a protein in the network) have few interactions and only a few nodes have large number of interactions. The latter are often referred to as "hubs" which are crucial in keeping the network intact (Vidal et al. 2011). We performed network topology analysis to infer the properties of the host proteins targeted by the viral proteins in the context of the human protein interactome. We considered two important parameters - relative betweenness centrality (which reflects the amount of information that passes through this protein in the human interactome) and degree (number of binding partners in the human interactome) of the host proteins targeted by each virus. The targets of all the viruses showed higher betweenness centrality and degree as compared to an average protein in the human interactome (Fig. 1C and Fig. 1D). This shows that viruses, by targeting "hubs" and proteins that serves as key communication nodes, have evolved the best way to disrupt the scale-free human interactome. This topological property thereby shows how viruses having small genomes achieve the maximal effect in rewiring the human interactome to benefit viral survival and replication. Our analysis is in agreement with several previous studies, which have highlighted this property (Pichlmair et al. 2012, Rozenblatt-Rosen et al. 2012, de Chassey et al. 2008, Durmuş et al. 2015, Franzosa and Xia 2011). We propose that this could be a general principle for all viruses. 
bioRxiv preprint doi: https://doi.org/10.1101/548909; this version posted February 13, 2019. The copyright holder for this preprint (which was not certified by peer review) is the author/funder. All rights reserved. No reuse allowed without permission.

A)
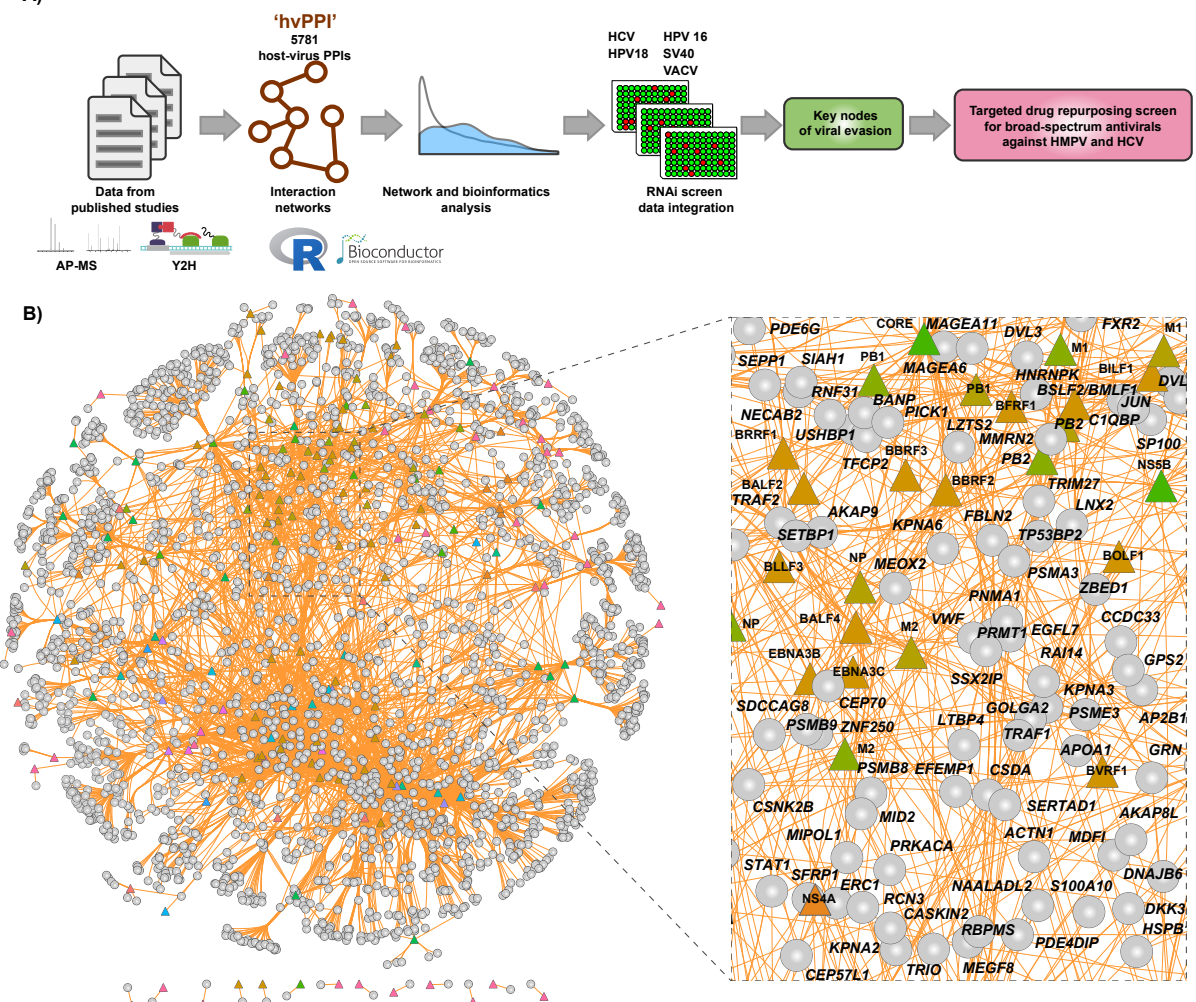

C)

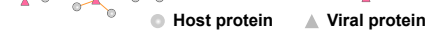

D)
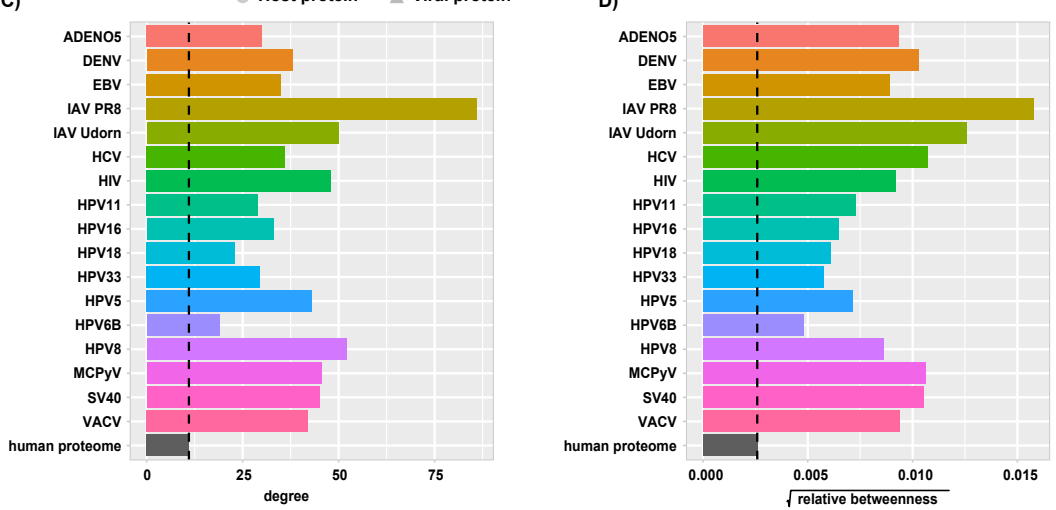

Fig. 1: Meta-analysis of host-virus interactions involving 17 different viruses. (A) Schematic view of the analysis workflow. (B) Network view of the 'hvPPI' containing host-virus interactions from 17 different viruses. The edges are coloured in orange. Node shapes are in circles and triangles for host and viral protein, respectively. A zoomed-in snippet shows the names of selected host and viral proteins. (C) and (D) Barplot showing the median degree and betweenness centrality of targets of each virus as compared to the human proteome. 


\section{Host factors with higher disordered regions are enriched in hvPPI networks}

Proteins usually fold into stable three-dimensional structures that mediate specific functions. In addition, there are sub-structures in proteins termed "intrinsically disordered regions (IDRs)" which lack stable structures under normal physiological conditions. IDRs are required for multiple cellular functions even though they lack these defined structures (Oldfield and Dunker 2014). Many studies have highlighted the presence of such IDRs in viral proteins (Xue et al. 2014, Tamarozzi and Giuliatti 2018, Dyson and Wright 2018), such as E6 from human papilloma virus, that are crucial for hijacking the cellular machinery. We analysed the host proteins from the hvPPI for presence of IDRs using the prediction software IUPred (Meszaros et al. 2018). We found a statistically significant enrichment (p-value $<6.246 \times 10^{-06}$ ) of IDRs in the host proteins targeted by viruses (Fig. 2A and Fig. S2A). We then identified the subnetwork in the hvPPI which contained the top host targets with high disorderness score (Fig. 2B). The top five proteins with large IDRs include CD44 antigen (CD44), Serine/arginine repetitive matrix protein 2 (SRRM2), Myristoylated alanine-rich C-kinase substrate (MARCKS), BAG family molecular chaperone regulator 3 (BAG3) and Mitochondrial antiviral-signalling protein (MAVS) (Fig. 2C). CD44 is a marker of exhausted CD8+ T cells (Wherry and Kurachi 2015) and replication of HCV in T cells was shown to decrease cell proliferation by inhibiting CD44 expression and signalling (Kondo et al. 2009). SRRM2 is a serine/arginine-rich protein involved in RNA splicing (Blencowe et al. 2000). SRRM2 is differentially phosphorylated in HIV-1 infected cells and absence of SRRM2 lead to increased HIV-1 gene expression, since it regulates the splicing of HIV-1 (Wojcechowskyj et al. 2013). In the hvPPI, SRRM2 is targeted by multiple viral proteins including the Tat protein from HIV-1. Tat protein has an important role in the stimulation of the transcription of the long terminal repeat (LTR) (Das et al. 2011). In addition, NS1 protein from influenza B virus has also been reported to interact with SRRM2 (Patzina et al. 2017). Proteins of the MARCKS family are involved in a range of cellular processes including cell adhesion and migration (Arbuzova et al. 2002). MARCKS is a negative regulator of lipopolysaccharide (LPS)-induced Toll-like receptor 4 (TLR4) signalling in mouse macrophages (Mancek-Keber et al. 2012). MAVS is an adaptor protein in the RIG-I signalling pathway involved in the sensing of RNA. Ablasser et al. (2009) reported that double- stranded DNA serves as a template for RNA polymerase II and is transcribed into a 5' triphosphate containing double-stranded RNA, which activates the RIG-I signalling pathway. In the hvPPI, MAVS is targeted by several proteins from dsDNA viruses such as EBV and HPV. Altogether, our analysis shows that the IDR-high part of the human proteome is an essential part of the viral evasion strategy and some of the selected targets highlighted here could show novel insights into the viral evasion mechanisms. However, the very flexible protein structure of disordered proteins also makes them also difficult to target with drugs. 
A)
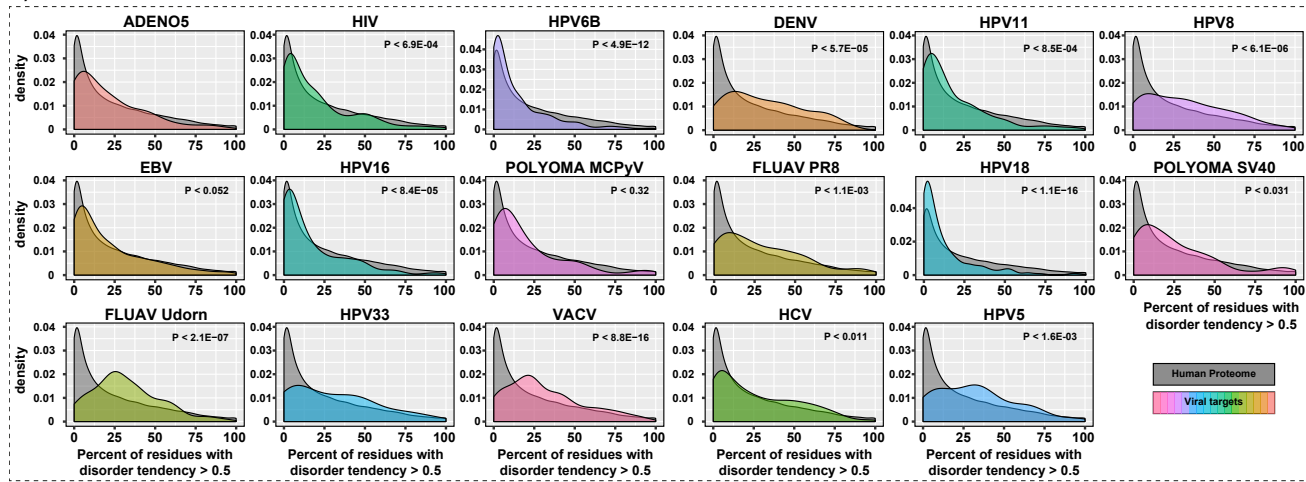

Percent of residues with
disorder tendency $>0.5$

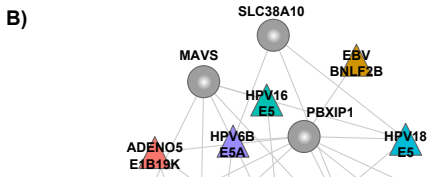

C)
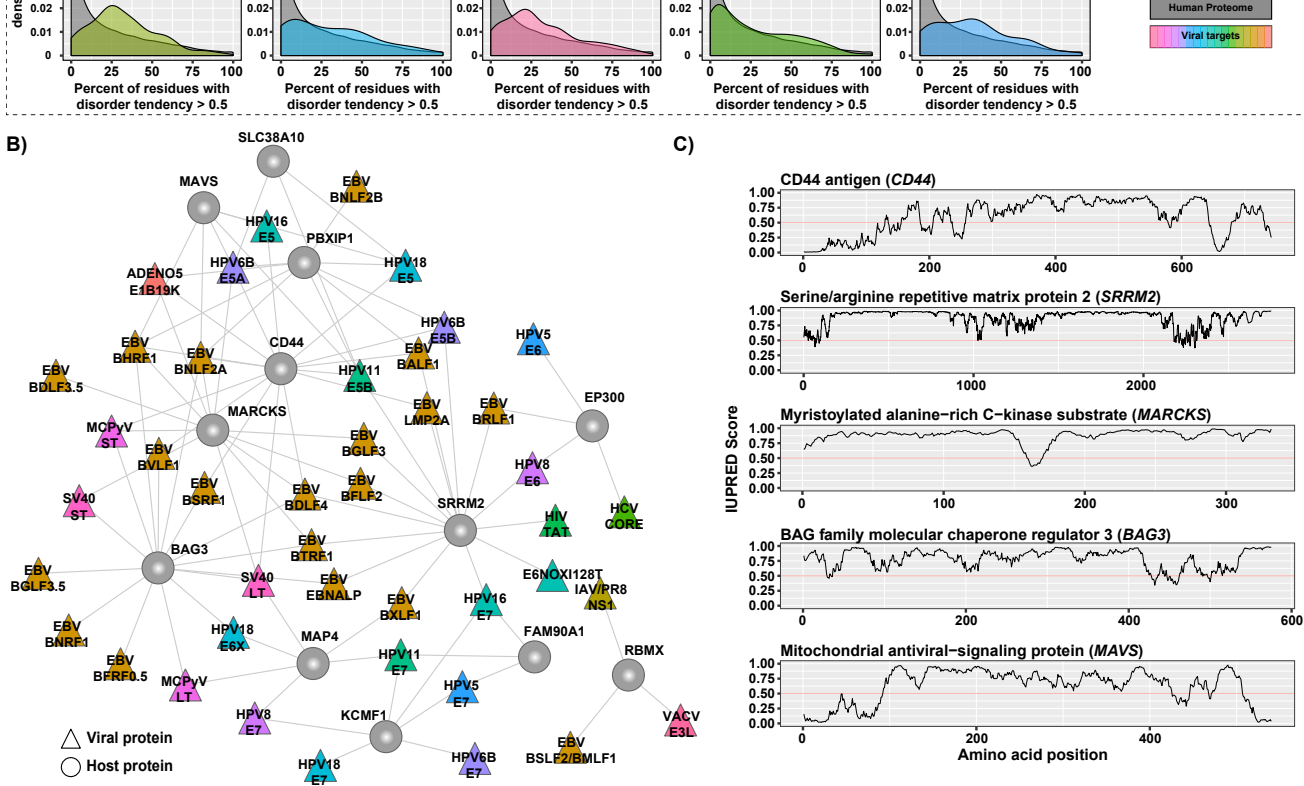

Fig. 2: Protein disorder analysis. (A) Density plot of the distribution of host proteins for each virus with percent of residues with disorder tendency greater than 0.5 as predicted by the IUPred software as compared to the human proteome. (B) Sub-network of hvPPI with the highly targeted and highlydisordered proteins. (C) Line plots showing the IUPred Score (a measure of the disordered region) for the five selected host proteins from the sub-network. A IUPred score of $>0.5$ is considered disordered.

\section{Viral proteins target core signalling pathways and process networks}

To assess the signalling pathways and cellular processes within the hvPPI, we identified highly connected subnetworks within hvPPI network. We constructed a host-host interaction network based on the host targets in the hvPPI and identified a number of highly connected subnetworks/clusters (Fig. 3). We then performed a gene-set enrichment analysis of significantly enriched biological processes. We found one or more enriched processes for each of this subnetwork including core cellular processes such as proteasome, spliceosome, protein translation, protein/RNA transport, and cell cycle. Next we listed the viruses that target one or more of these processes, and found that almost all the core pathways and processes are targeted by all the 17 viruses that are part of the hvPPI (Fig. S3). This analysis highlights the core components of the cellular process subnetworks which are targeted as part of the viral evasion strategies and thus could be broad-spectrum antiviral hot-spots from a therapeutic point of view. 


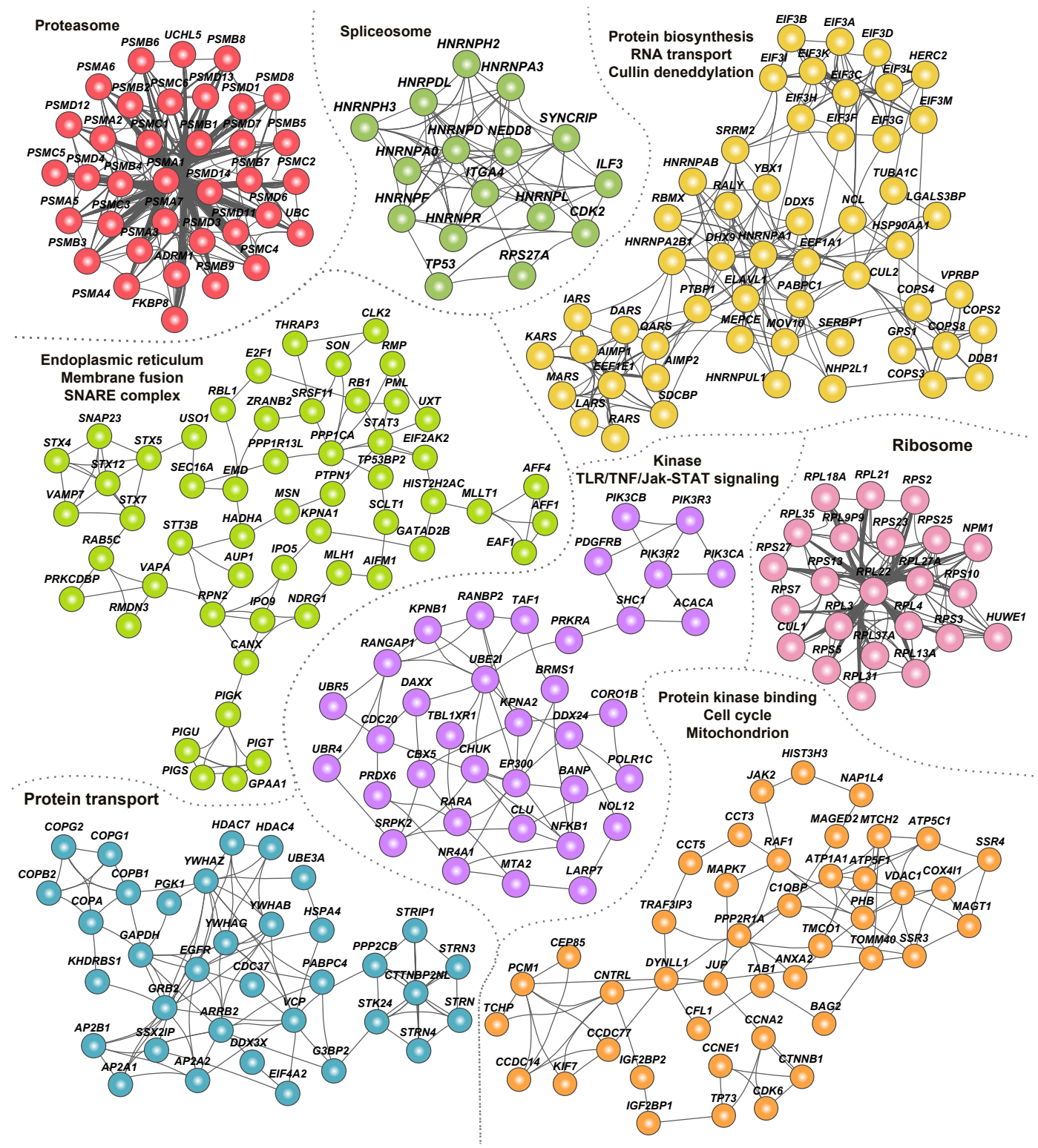

Fig. 3: Clusters of hvPPI involved in core cellular processes. Network view of the 'clusters' or highlyconnected sub-networks and their associated cellular processes. Each cluster is marked in a unique color. 


\section{Enrichment analysis reveals commonality and specificity in sub-cellular localization of the host factors}

Given that the viral proteins were interacting with a large number of host proteins, we analysed the sub-cellular location of the host proteins. We performed gene-set enrichment analysis of sub-cellular localization information provided by UniProt database. We binned the localization into 11 compartments and estimated the percent of host proteins in a given compartment as compared to the total number of host proteins targeted by a given virus. We found that the viral targets were distributed across multiple subcellular compartments with cytoplasm being the most common (Fig. S4A). The hvPPI includes two different strains of IAV - PR8 (H1N1) and Udorn (H3N2). The subcellular localization analysis showed that both strains were enriched for nuclear proteins. Nonstructural protein 1 (NS1) from both the strains had the highest number of nuclear targets but their targets were very different (Fig. 4A). NS1 of Udorn was enriched for a large number of histones as compared to NS1 of PR8 that had large number of heterogeneous nuclear ribonucleoproteins (hnRNPs), such as HNRNPU - a known restriction factor for many viruses. This corroborates with the observation that NS1 protein has short linear histone mimicry motifs that can suppress the host antiviral response (Marazzi et al. 2012). In our analysis, we found that it is NS1 of Udorn that has a histone mimicry motif "ARSK" (Fig. S4B). Similarly, HPV11 and HPV18 E5 proteins interact more often with host proteins located in the endoplasmic reticulum (ER). We found both common and specific subsets of ER proteins targeted by the E5 protein (Fig. 4B). HPV18 E5 protein ER targets were enriched for phospholipid biosynthesis as well as GPI anchor related proteins, such as phosphatidylinositol glycan anchor biosynthesis class $\mathrm{S} / \mathrm{T} / \mathrm{U}$ (PIGS, PIGT and PIGU), glycosylphosphatidylinositol anchor attachment 1 (GPAA1) and phosphatidylserine synthase 2 (PTDSS2). HPV11 E5 protein ER targets were enriched for ER-associated ubiquitin-dependent protein catabolism involving host proteins such as ER degradation enhancing alpha-mannosidase-like protein 3 (EDEM3) and ER lipid raft associated 1 (ERLIN1). ER targets common to HPV18 and HPV11 E5 protein were enriched for unfolded protein response, N-linked glycosylation and protein folding involving host proteins such as SRP receptor alpha/beta subunit (SRPRA/SRPRB) and catalytic subunits of the oligosaccharyltransferase complex (STT3A and STT3B). Two independent CRISPR/Cas9 screening studies identified multiple ER associated components including STT3A and STT3B as host factors for DENV, Zika virus (ZIKV) and Japanese encephalitis virus (JEV) (Zhang et al. 2016, Marceau et al. 2016). The non-canonical function of STT3A and STT3B is required for DENV replication and that NS1 protein of DENV interacts with these proteins (Marceau et al. 2016). Our orthogonal approach can lead to the identification of critical host factors, and similar functions of ER components, such as STT3A and STT3B, are used by HPV11 and HPV18 as well. Thus targeting the non-canonical function of STT3A and STT3B could be a broad antiviral strategy. Overall, the enrichment analysis clearly shows that there is commonality and specificity in the subcellular targets of the viral proteins and that detailed interrogation of these targets can give vital clues into the viral evasion mechanisms. 


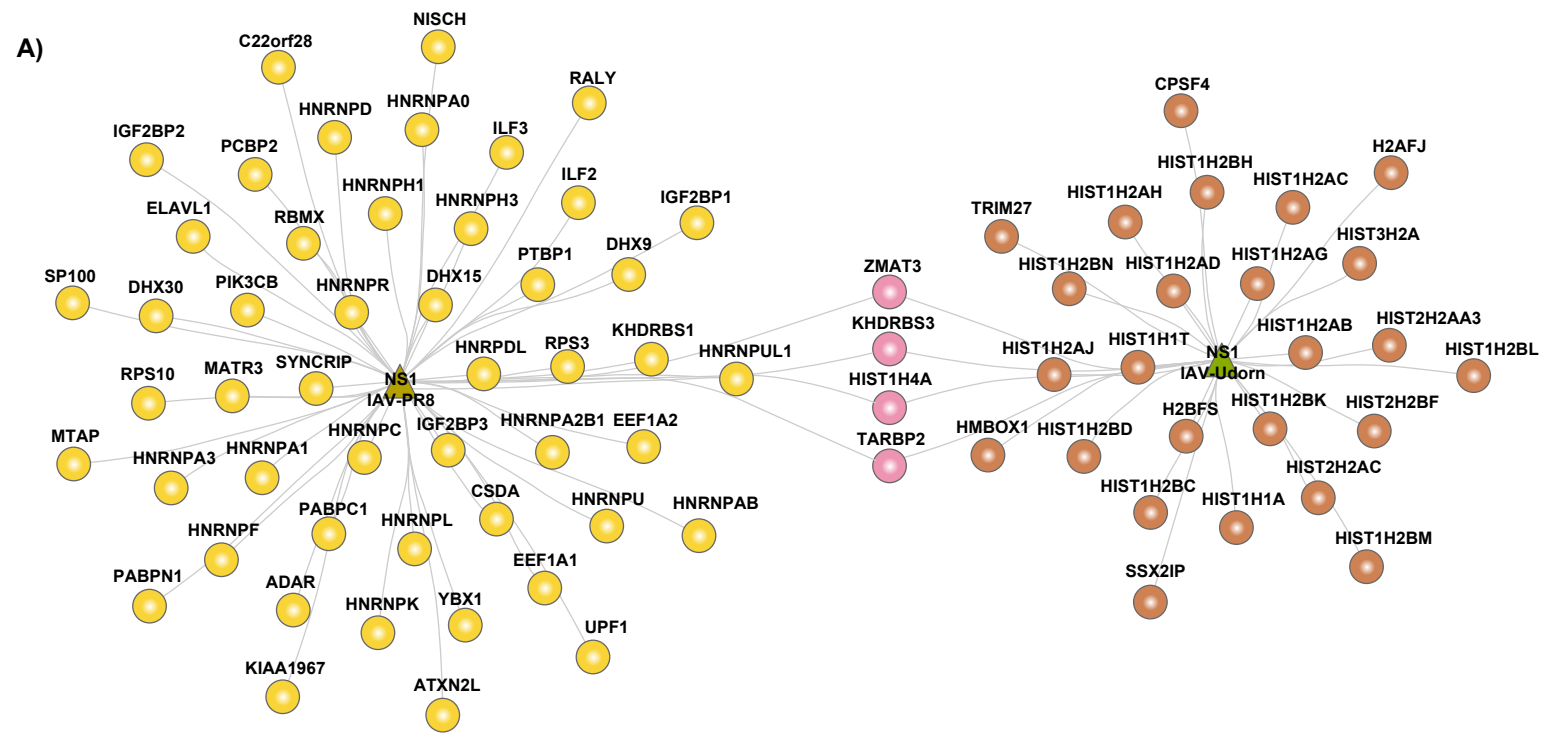

B)

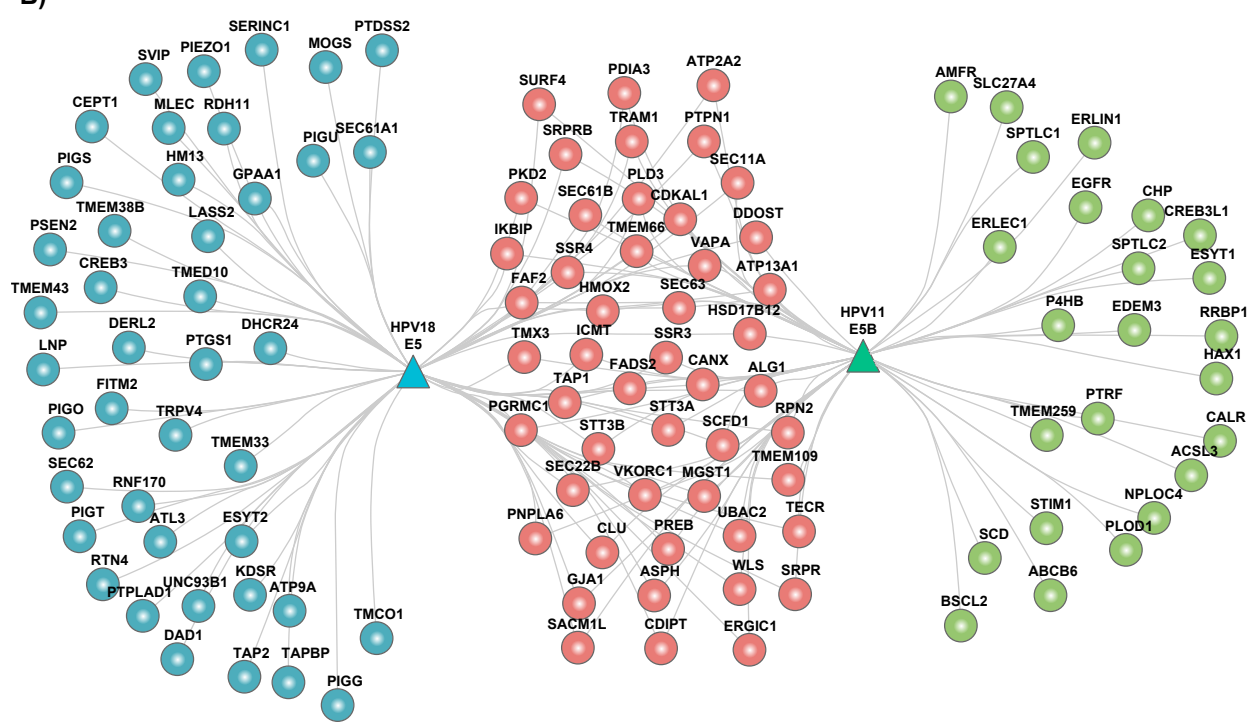

Fig. 4: Sub-cellular localization of the host proteins. (A) Network view of nuclear interactome of NS1 protein from IAV strains PR8 and Udorn. (B) Network view of ER interactome of E5 protein from HPV18 and HPV11. 


\section{Integrative analysis of host-virus interactome and RNAi data reveals COPI system as commonly targeted proviral process}

RNAi screens have been a powerful high-throughput method to identify various cellular functions, including for identification of host restriction factors of viruses (Hirsch 2010). In order to explore the functional relevance of the host targets in the hvPPI, we integrated it with five published RNAi screens that performed genome-wide or druggable-genome-wide RNAi screens for identifying host factors of HCV (Tai et al. 2009), HPV18 (Schmidt et al. 2013), HPV16 (Aydin et al. 2014), SV40 (Snijder et al. 2012) and VACV (Mercer et al. 2012).

A)

\begin{tabular}{|c|c|}
\hline $\begin{array}{c}\text { Gene } \\
\text { symbol }\end{array}$ & Gene name \\
\hline$A B C B 10$ & ATP-binding cassette sub-family B member 10 , mito chondrial \\
\hline$A B C B 7$ & ATP-binding cassette sub-family B member 7 , mito cho ndrial \\
\hline$A C A C A$ & Acetyl-Co A carbo xylase 1 \\
\hline ATP1A1 & So dium/potassium-transporting ATP ase subunit alpha-1 \\
\hline BCAP31 & B-cell receptor-asso ciated protein 31 \\
\hline$B C L 6$ & B-cell lymphoma 6 protein \\
\hline BZRAP1 & Peripheral-type benzo diazepine recepto r-associated protein 1 \\
\hline COPA & Coatomer subunit alpha \\
\hline COPB1 & Coatomer subunit beta 1 \\
\hline COPB2 & Coatomer subunit beta 2 \\
\hline COPG1 & Coatomer subunit gamma-1 \\
\hline COPZ1 & Coato mer subunit zeta-1 \\
\hline DNAJC16 & DnaJ ho molog subfamily C member 16 \\
\hline DPF1 & Zinc finger protein neuro-d4 \\
\hline EIF3A & Eukaryo tic translation initiation factor 3 subunit $A$ \\
\hline EIF3C & Eukaryo tic translation initiation factor 3 subunit $C$ \\
\hline EIF3D & Eukaryo tic translation initiation factor 3 subunit $D$ \\
\hline ERG & Transcriptional regulator ERG \\
\hline HCK & Tyrosine-protein kinase $\mathrm{HCK}$ \\
\hline JAK2 & Tyrosine-protein kinase JAK2 \\
\hline KIF17 & Kinesin-like protein KIF17 \\
\hline KPNB1 & Importin subunit beta-1 \\
\hline LPLUNC1 & $\begin{array}{l}\text { Long palate, lung and nasal epithelium } \\
\text { carcinoma-associated protein } 1\end{array}$ \\
\hline$M A X$ & Protein max \\
\hline PKN2 & Serine/threo nine-protein kinase N2 \\
\hline PSMA1 & Proteasome subunit alpha type-1 \\
\hline PSMA3 & Proteasome subunit alpha type- 3 \\
\hline PSMC3 & $26 \mathrm{~S}$ protease regulato ry subunit $6 \mathrm{~A}$ \\
\hline PSMD14 & $26 \mathrm{~S}$ proteasome non-A TP ase regulatory subunit 14 \\
\hline RAB18 & Ras-related protein Rab-18 \\
\hline RABL3 & Rab-like protein 3 \\
\hline RACGAP1 & Rac GTP ase-activating protein 1 \\
\hline$R P L 4$ & 60S ribosomal protein $\mathrm{L} 4$ \\
\hline RPS13 & $40 \mathrm{~S}$ ribosomal protein $\mathrm{S} 13$ \\
\hline RPS24 & 40 S ribo so mal protein $\$ 24$ \\
\hline RPS27A & Ubiquitin-40S ribos somal protein $\mathrm{S} 27 \mathrm{a}$ \\
\hline TRIM 62 & Tripartite motif-containing protein 62 \\
\hline TSG101 & Tumor susceptibility gene 101 protein \\
\hline VPS39 & Vam6/Vps39-like protein \\
\hline WNK1 & Serine/threo nine-protein kinase WNK1 \\
\hline$X A B 2$ & Pre-mRNA-splicing factor SYF1 \\
\hline ZNF346 & Zinc finger protein 346 \\
\hline
\end{tabular}

B)

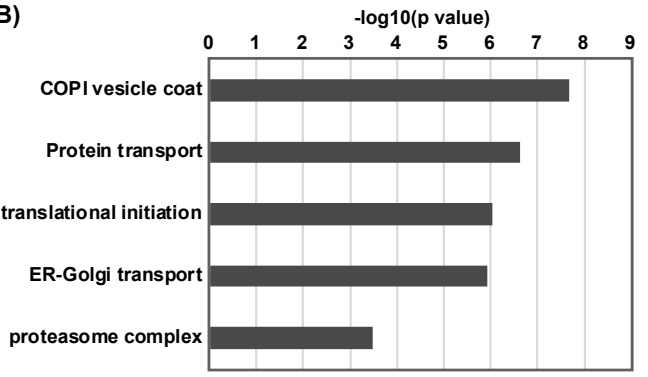

C)
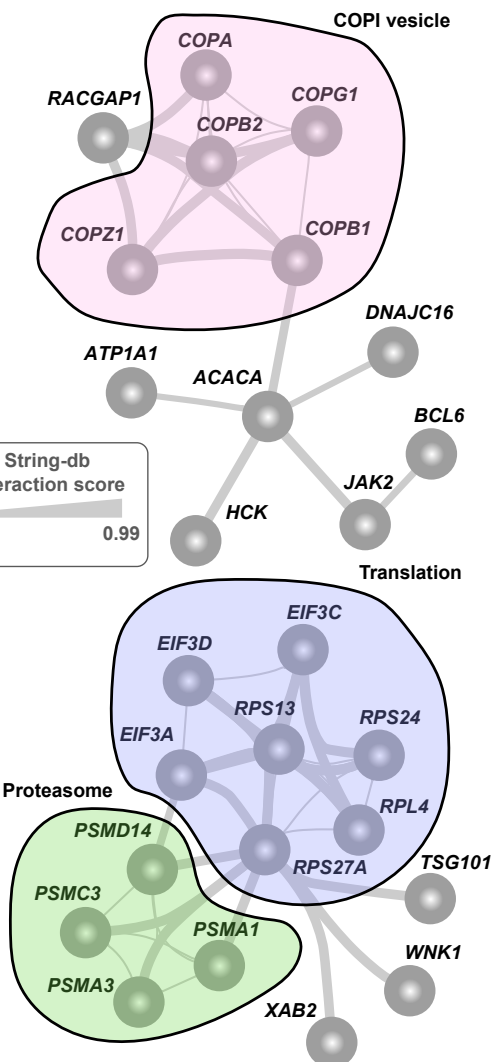

Fig. 5: Integration of hvPPI with RNAi screen. (A) Top proviral genes from RNAi screens that are also targeted by multiple viral proteins. (B) Barplot showing the significantly enriched cellular processes involving the top targeted and proviral genes. (C) Network view of top targets and their functional relevance. 
We found that host targets from the hvPPI were spread across the spectrum of genes with proviral as well as antiviral phenotype (Fig. S5), thus showing that targeting of the host protein by the virus could lead into any direction that favours the virus. We then investigated the top 50 proviral genes that are also targeted by the viral proteins as seen in the hvPPI. We identified 42 host proteins (Fig. 5A) that were significantly enriched for coatomer protein complex 1 (COPI), protein translation/transport and proteasome (Fig. 5B). This further substantiates the findings from the earlier section on the core cellular processes targeted by the viruses. Network analysis of these top hits showed high level on connectivity and crosstalk - for example between the translation and proteasome machinery (Fig. 5C). Vesicle carriers are involved in the transport of membranes and proteins. COPI system is one of the three vesicular carrier systems that is involved in the early secretory pathway (Beck et al. 2009, Lee et al. 2004, Bethune et al. 2006). Moreover, it has been pointed out that there is a strong similarity between vesicular transport and viral transport (viral entry to budding process) (Thaa et al. 2010); thus making COPI system important for the viral life cycle. SiRNAbased silencing of COPI lead to a defect in entry of IAV and disruption of the COPI complex inhibited the production of infectious progeny virus (Sun et al. 2013). Altogether, these top hits including the COPI system could serve as targets for developing therapeutic antiviral intervention strategies for a broad group of viruses.

\section{Combining host-virus and drug-gene interactions reveals novel activities of broad-spectrum antiviral agents against hepatitis $C$ virus and human metapneumovirus}

Our analyses pointed out that viral evasion mechanism observed in one virus could also be relevant for other viruses. Thus, we wanted to test if we could target viral replication of other viruses based on the results from the hvPPI analyses. To get an estimate of the druggability of the hvPPI, we obtained known drug-gene interactions from DGIdb (Cotto et al. 2018). The data from DGIdb included drug-gene interactions for 48 drugs that were investigational/experimental/approved safe-in-human antivirals compounds (Ianevski et al. 2018). Among these 48 broad-spectrum-antivirals, 28 of them had targets that are part of the hvPPI. Based on this overlap, we performed a targeted drug re-purposing screen with 35 of these 48 compounds (Table S1) to check for antiviral activity against and HCV, which is part of the hvPPI and human metapneumovirus (HMPV) which is not in the hvPPI.. We tested 35 broadspectrum-antivirals against GFP-expressing HMPV NL/1/00 strain (de Graaf et al. 2007). Seven different concentrations of the compounds were added to HMPV or mock-infected cells. Cell viability was controlled after 48 hours and HMPV-induced GFP expression was tested to determine compound efficiency. After the initial screening, we identified five compounds, which lowered GFP-expression without detectable cytotoxicity (with $S I>3$ ). We repeated the experiment with these compounds. The experiment confirmed novel activity of azacytidine, lopinavir, nitazoxanide, itraconazole and oritavancin against HMPV (Fig. 6A and Table 1). Similarly, we examined toxicity and antiviral activity of broad-spectrum-antivirals against GFP-expressing HCV in Huh-7.5 cells using previously described procedures (Kim et al. 2016). Our test identified azithromycin, cidofovir, oritavancin, dibucaine, gefitinib, minocycline and pirlindole mesylate as novel anti-HCV agents with $S I>3$ (Fig. 6B and Table 1).

In summary, our meta-analysis approach of the hvPPI could provide novel and faster approaches for the re-purposing of existing drugs as antiviral agents. 


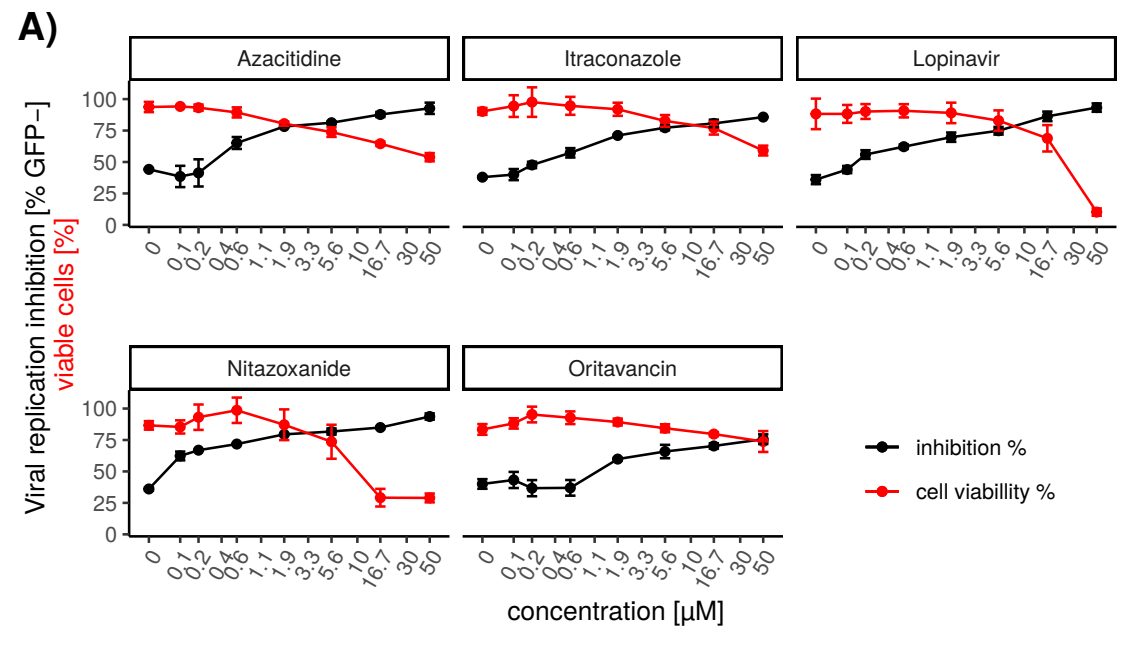

B)

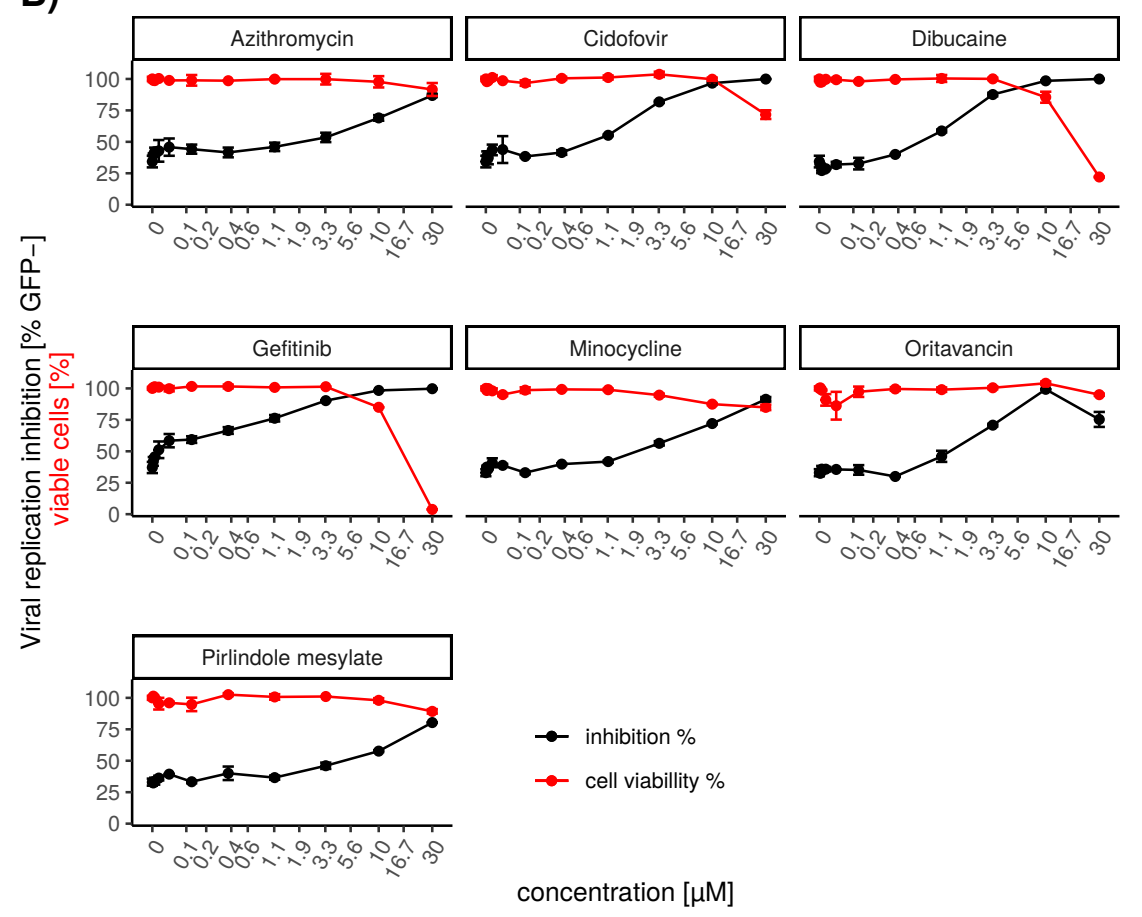

Fig. 6: Drug re-purposing screen for novel broad-spectrum antivirals (A) At non-cytotoxic concentrations selected broad-spectrum antiviral agents inhibit HMPV-mediated GFP expression in Huh-7.5 cells. Efficacy of antiviral agents as shown by the percent of GFP-expressing cells decreasing in response to increasing concentration of antiviral agents (Mean $\pm \mathrm{SD}, \mathrm{n}=3$ ). Cytotoxicity of antiviral agents as shown by the percent of live cells (Mean $\pm \mathrm{SD}, \mathrm{n}=3$ ). (B) At non-cytotoxic concentrations selected broad-spectrum antiviral agents inhibit HCV-mediated GFP expression in Huh7.5 cells (Mean $\pm \mathrm{SD}, \mathrm{n}=3$ ). 
Table 1: Characteristics, half-maximal cytotoxic concentration $\left(C C_{50}\right)$, the half-maximal effective concentration $\left(E C_{50}\right)$ and minimal selectivity indexes $\left(S I=\frac{C C_{50}}{E C_{50}}\right)$ for selected broad-spectrum antivirals. The measurements were repeated three times $(\mathrm{p}<0.05)$.

\begin{tabular}{|c|c|c|c|c|c|c|c|c|c|}
\hline Compound & $\begin{array}{l}\text { ChEMBL } \\
\text { ID }\end{array}$ & $\begin{array}{l}\text { Approved } \\
\text { use }\end{array}$ & Virus & $\begin{array}{l}\text { Cell } \\
\text { line }\end{array}$ & $\begin{array}{l}\mathrm{CC}_{50} \\
{[\mu \mathrm{M}]}\end{array}$ & $\begin{array}{l}\mathrm{EC}_{50} \\
{[\mu \mathrm{M}]}\end{array}$ & SI & $\begin{array}{c}\text { Clinical trials for } \\
\text { antiviral } \\
\text { treatment } \\
\text { (clinicaltrials.gov) }\end{array}$ & $\begin{array}{c}\text { other } \\
\text { reported } \\
\text { antiviral activity }\end{array}$ \\
\hline Azithromycin & 529 & antibiotic & $\mathrm{HCV}$ & $\begin{array}{l}\text { Huh- } \\
7.5\end{array}$ & $<30$ & $>10$ & $>3$ & $\begin{array}{l}\text { HPV, CMV, HSV } \\
\text { AdV, BKV }\end{array}$ & \\
\hline Cidofovir & 152 & anti-CMV & $\mathrm{HCV}$ & $\begin{array}{l}\text { Huh- } \\
7.5\end{array}$ & $>30$ & $<1$ & $>30$ & $\begin{array}{l}\text { BKV, HPV, HSV, } \\
\text { KSHV, AdV }\end{array}$ & \\
\hline Dibucaine & 1086 & $\begin{array}{c}\text { local } \\
\text { anesthetic }\end{array}$ & $\mathrm{HCV}$ & $\begin{array}{c}\text { Huh- } \\
7.5\end{array}$ & 11.6 & 1.4 & 8.4 & & EV-B (Ulferts et al. 2016) \\
\hline Gefitinib & 939 & anti cancer & $\mathrm{HCV}$ & $\begin{array}{c}\text { Huh- } \\
7.5\end{array}$ & 11.6 & 1.1 & 10.8 & & $\begin{array}{l}\text { VACV, BKV, CMV } \\
\text { (Randhawa et al. 2010, } \\
\text { Langhammer et al. 2011, } \\
\text { Schleiss et al. 2008) }\end{array}$ \\
\hline Minocycline & 1434 & antibiotic & $\mathrm{HCV}$ & $\begin{array}{c}\text { Huh- } \\
7.5\end{array}$ & 11.6 & 5.2 & $>5.7$ & HIV & $\begin{array}{l}\text { DENV, WNV (Lai et al. } \\
\text { 2018, Michaelis et al. 2007) }\end{array}$ \\
\hline Oritavancin & 1688530 & antibiotic & $\mathrm{HCV}$ & $\begin{array}{c}\text { Huh- } \\
7.5\end{array}$ & $>30$ & $<3$ & $>10$ & & $\begin{array}{l}\text { EBOV, MERS-CoV, } \\
\text { SARS-CoV (Zhou et al. } \\
2016)\end{array}$ \\
\hline $\begin{array}{l}\text { Pirlindole } \\
\text { mesylate }\end{array}$ & 32350 & $\begin{array}{c}\text { anti- } \\
\text { depressant }\end{array}$ & $\mathrm{HCV}$ & $\begin{array}{c}\text { Huh- } \\
7.5\end{array}$ & $>30$ & $<10$ & $>3$ & & EV-B (Ulferts et al. 2016) \\
\hline Azacitidine & 1489 & anti cancer & HPMV & RPE & $>50$ & 1.2 & 41.7 & & $\begin{array}{l}\text { HIV-1, HTLV-1, IAV, Rift } \\
\text { Valley fever virus } \\
\text { (Bouchard et al. 1990, } \\
\text { Rawson et al. 2016, Pauly } \\
\text { and Lauring 2015, Ianevski } \\
\text { et al. 2018) }\end{array}$ \\
\hline Itraconazole & 22587 & antifungal & HPMV & RPE & 28.2 & 5 & 5.6 & & $\begin{array}{l}\text { EV71, HRV (Gao et al. } \\
\text { 2015, Shim et al. 2016) }\end{array}$ \\
\hline Lopinavir & 729 & $\begin{array}{l}\text { anti } \\
\text { retroviral }\end{array}$ & HPMV & RPE & 29.7 & 3.6 & 8.3 & SINV & $\begin{array}{l}\text { EBOV, MERS-CoV, } \\
\text { SARS-CoV (Zhou et al. } \\
2016 \text { ) }\end{array}$ \\
\hline Nitazoxanide & 1401 & antiparasitic & HPMV & RPE & $>50$ & 2.6 & $>11.5$ & $\begin{array}{l}\text { NoV, AdV, HRV, } \\
\text { HCV, IAV }\end{array}$ & $\begin{array}{l}\text { RUBV, MERS-CoV, } \\
\text { VACV, ZIKV (Hickson } \\
\text { et al. 2018, Rossignol } 2016 \\
\text { May-Jun, Perelygina et al. } \\
\text { 2017, Cao et al. 2017) }\end{array}$ \\
\hline Oritavancin & 1688530 & antibiotic & HMPV & $\mathrm{RPE}$ & $>50$ & 2.6 & $>11.5$ & & $\begin{array}{c}\text { EBOV, MERS-CoV, } \\
\text { SARS-CoV (Zhou et al. } \\
2016 \text { ) }\end{array}$ \\
\hline
\end{tabular}




\section{Discussion}

Using integrative analysis of orthogonal datasets our study provides a comprehensive view of viral evasion mechanisms.

In particular our analysis of the hvPPI network revealed that all the viruses have evolved to target proteins that are central and have strong control over the human interactome. Host proteins targeted by viruses contain a high proportion of intrinsically disordered regions. We identified the core cellular processes and associated proteins that are targeted by all viruses. Detailed comparative analysis of the subcellular localization of the host proteins showed commonality and specificity both between viral proteins from different strains of the same virus; and between viruses. Integrating hvPPI with functional RNAi screens showed that a large portion of the hvPPI are host factors of one or more virus. hvPPI data-based drug re-purposing screen identified novel activities for various broad-spectrum antivirals against HMPV and $\mathrm{HCV}$.

This unique dataset can be used for further detailed interrogation of the mechanisms behind viral evasion. This could serve as a starting point for identifying novel host targets and generating hypothesis in the context of viral evasion and development of pan-viral therapeutic intervention strategies. The methods described here also provide unique ways of dissecting the orthogonal datasets. Various analyses from this study have highlighted the existence on pan-viral evasion points that could be utilised for the development of host-directed antiviral therapies. It is also intriguing to see that there is commonality and specificity at the level of subcellular localization of the viral targets. Our analyses have underlined some salient features in the context of IAV, HPV, DENV and HCV. Further detailed analysis in this context along with protein sequence features, such as Short Linear Motifs (SLiMs) (Davey et al. 2011) would provide novel insights as well as deeper understanding of how small sequence features are involved in the hijacking of the host machinery. Integration of such data with known druggene interactions provides a clear estimate of the druggable proportion in the hvPPI. Our meta-analysis approach of the hvPPI could provide novel avenues of re-purposing existing drugs for antiviral targeting strategies.

Our study demonstrated that azacytidine, itraconazole, lopinavir, nitazoxanide, and oritavancin are novel experimental anti-HMPV agents, whereas cidofovir, dibucaine, azithromycin, gefitinib, minocycline, oritavancin, and pirlindole mesylate are novel anti-HCV drugs. These drugs have already been used as investigational agents or experimental drug in different virus infections. Although, the mechanisms of action of these compounds in inhibiting the viral infections are still unknown, this agent could inhibit steps of viral infections, which preceded reporter protein expression from viral RNA. In summary, our results indicate that existing broad-spectrum-antivirals could be re-purposed to other viral infections. Re-purposing these therapeutics could save resources and time needed for development of novel drugs to quickly address unmet medical needs, because safety profiles of these agents are available. Effective treatment with broad-spectrum-antivirals may shortly become available, pending the results of further pre-clinical studies and clinical trials. This, in turn, means that some broadspectrum-antivirals could be used for rapid management of new or emerging drug-resistant strains, as well as for first-line treatment or for prophylaxis of acute virus infections or for viral co-infections. The most effective and tolerable compounds could expand the available 
therapeutics for the treatment of viral diseases, improving preparedness and the protection of the general population from viral epidemics and pandemics.

\section{Conflict of Interest Statement}

The authors declare that the research was conducted in the absence of any commercial or financial relationships that could be construed as a potential conflict of interest.

\section{Author Contributions}

R.K.K. and K.B. performed all the bioinformatics and network analysis. A.I., T.T.T., P.I.A, M.T., E.Z., U.D., A.V., R.J.C., H.K-K., A.B., T.T., A.M., V.O., M.B., M.W.A., D.S., M.K., M.P.W. and D.K. contributed to the drug re-purposing screen. D.K. supervised the drug repurposing screen. G.S.F. and B.S. provided data. R.K.K. conceived and supervised the study. R.K.K., D.K. and K.B. wrote the manuscript. All authors contributed, read and approved the manuscript.

\section{Funding}

This work was funded by the Research Council of Norway (FRIMEDBIO "Young Research Talent" Grant 263168 to R.K.K.; and Centres of Excellence Funding Scheme Project 223255/F50 to CEMIR), Onsager fellowship from NTNU (to R.K.K.). European Regional Development Fund, the Mobilitas Pluss Project MOBTT39 (to D.K.) and by the National Research Foundation of Korea (NRF) grant funded by the Korea government (MSIT, NRF2017M3A9G6068246, Gyeonggi-do to M.P.W.).

\section{Acknowledgments}

We thank Christian Sinzger and group for the EGFP-expressing TB40E CMV strain. We thank ViroNovative and Erasmus MC for the GFP-expressing HMPV NL/1/00 strain.

\section{References}

A. Ablasser, F. Bauernfeind, G. Hartmann, E. Latz, K. A. Fitzgerald, and V. Hornung. RIG-I-dependent sensing of poly $(\mathrm{dA}: \mathrm{dT})$ through the induction of an RNA polymerase III-transcribed RNA intermediate. Nat Immunol, 10(10):1065-72, October 2009. ISSN 1529-2916 (Electronic) 1529-2908 (Linking). doi: 10. 1038/ni.1779.

A. Arbuzova, A. A. Schmitz, and G. Vergeres. Cross-talk unfolded: MARCKS proteins. Biochem J, 362(Pt 1):1-12, February 2002. ISSN 0264-6021 (Print) 0264-6021 (Linking).

I. Aydin, S. Weber, B. Snijder, P. Samperio Ventayol, A. Kuhbacher, M. Becker, P. M. Day, J. T. Schiller, M. Kann, L. Pelkmans, A. Helenius, and M. Schelhaas. Large scale RNAi reveals the requirement of nuclear envelope breakdown for nuclear import of human papillomaviruses. PLoS Pathog, 10(5):e1004162, May 2014. ISSN 1553-7374 (Electronic) 1553-7366 (Linking). doi: 10.1371/journal.ppat.1004162.

T. H. Bacon, M. J. Levin, J. J. Leary, R. T. Sarisky, and D. Sutton. Herpes simplex virus resistance to acyclovir and penciclovir after two decades of antiviral therapy. Clin Microbiol Rev, 16(1):114-28, January 2003. ISSN 0893-8512 (Print) 0893-8512 (Linking).

Gary D. Bader and Christopher WV Hogue. An automated method for finding molecular complexes in large protein interaction networks. BMC Bioinformatics, 4:2, January 2003. ISSN 1471-2105. doi: 10.1186/ 1471-2105-4-2.

J. Batra, J. F. Hultquist, D. Liu, O. Shtanko, J. Von Dollen, L. Satkamp, G. M. Jang, P. Luthra, T. M. Schwarz, G. I. Small, E. Arnett, M. Anantpadma, A. Reyes, D. W. Leung, R. Kaake, P. Haas, C. B. Schmidt, L. S. Schlesinger, D. J. LaCount, R. A. Davey, G. K. Amarasinghe, C. F. Basler, and N. J. Krogan. Protein Interaction Mapping Identifies RBBP6 as a Negative Regulator of Ebola Virus Replication. Cell, 175(7): 
1917-1930 e13, December 2018. ISSN 1097-4172 (Electronic) 0092-8674 (Linking). doi: 10.1016/j.cell.2018. 08.044 .

R. Beck, M. Ravet, F. T. Wieland, and D. Cassel. The COPI system: Molecular mechanisms and function. FEBS Letters, 583(17):2701-2709, September 2009. ISSN 0014-5793. doi: 10.1016/j.febslet.2009.07.032.

J. Bethune, F. Wieland, and J. Moelleken. COPI-mediated transport. J Membr Biol, 211(2):65-79, 2006. ISSN 0022-2631 (Print) 0022-2631 (Linking). doi: 10.1007/s00232-006-0859-7.

Janos X. Binder, Sune Pletscher-Frankild, Kalliopi Tsafou, Christian Stolte, Seán I. O’Donoghue, Reinhard Schneider, and Lars Juhl Jensen. COMPARTMENTS: Unification and visualization of protein subcellular localization evidence. Database, 2014, January 2014. doi: 10.1093/database/bau012.

B. J. Blencowe, G. Bauren, A. G. Eldridge, R. Issner, J. A. Nickerson, E. Rosonina, and P. A. Sharp. The SRm160/300 splicing coactivator subunits. RNA, 6(1):111-20, January 2000. ISSN 1355-8382 (Print) 13558382 (Linking).

J. Bouchard, M. C. Walker, J. M. Leclerc, N. Lapointe, R. Beaulieu, and L. Thibodeau. 5-azacytidine and 5-azadeoxycytidine inhibit human immunodeficiency virus type 1 replication in vitro. Antimicrobial Agents and Chemotherapy, 34(2):206-209, February 1990. ISSN 0066-4804.

Andrew G. Bowie and Leonie Unterholzner. Viral evasion and subversion of pattern-recognition receptor signalling. Nature Reviews Immunology, 8(12):911-922, December 2008. ISSN 1474-1741. doi: 10.1038/ nri2436.

Rui-Yuan Cao, Yong-fen Xu, Tian-Hong Zhang, Jing-Jing Yang, Ye Yuan, Pei Hao, Yi Shi, Jin Zhong, and Wu Zhong. Pediatric Drug Nitazoxanide: A Potential Choice for Control of Zika. Open Forum Infectious Diseases, 4(1), January 2017. doi: 10.1093/ofid/ofx009.

X. Carnec, L. Quan, W. C. Olson, U. Hazan, and T. Dragic. Anti-CXCR4 monoclonal antibodies recognizing overlapping epitopes differ significantly in their ability to inhibit entry of human immunodeficiency virus type 1. J Virol, 79(3):1930-3, February 2005. ISSN 0022-538X (Print) 0022-538X (Linking). doi: 10.1128/ JVI.79.3.1930-1933.2005.

K. C. Cotto, A. H. Wagner, Y. Y. Feng, S. Kiwala, A. C. Coffman, G. Spies, A. Wollam, N. C. Spies, O. L. Griffith, and M. Griffith. DGIdb 3.0: A redesign and expansion of the drug-gene interaction database. Nucleic Acids Res, 46(D1):D1068-D1073, January 2018. ISSN 1362-4962 (Electronic) 0305-1048 (Linking). doi: $10.1093 /$ nar/gkx1143.

A. T. Das, A. Harwig, and B. Berkhout. The HIV-1 Tat protein has a versatile role in activating viral transcription. J Virol, 85(18):9506-16, September 2011. ISSN 1098-5514 (Electronic) 0022-538X (Linking). doi: 10.1128/JVI.00650-11.

N. E. Davey, G. Trave, and T. J. Gibson. How viruses hijack cell regulation. Trends Biochem Sci, 36(3): 159-69, March 2011. ISSN 0968-0004 (Print) 0968-0004 (Linking). doi: 10.1016/j.tibs.2010.10.002.

B. de Chassey, V. Navratil, L. Tafforeau, M. S. Hiet, A. Aublin-Gex, S. Agaugué, G. Meiffren, F. Pradezynski, B. F. Faria, T. Chantier, M. Le Breton, J. Pellet, N. Davoust, P. E. Mangeot, A. Chaboud, F. Penin, Y. Jacob, P. O. Vidalain, M. Vidal, P. André, C. Rabourdin-Combe, and V. Lotteau. Hepatitis C virus infection protein network. Molecular Systems Biology, 4:230, 2008. ISSN 1744-4292. doi: 10.1038/msb.2008. 66 .

Miranda de Graaf, Sander Herfst, Eefje J. A. Schrauwen, Bernadette G. van den Hoogen, Albert D. M. E. Osterhaus, and Ron A. M. Fouchier. An improved plaque reduction virus neutralization assay for human metapneumovirus. Journal of Virological Methods, 143(2):169-174, August 2007. ISSN 0166-0934. doi: 10.1016/j.jviromet.2007.03.005.

Saliha Durmuş, Tunahan Çakır, Arzucan Özgür, and Reinhard Guthke. A review on computational systems biology of pathogen-host interactions. Frontiers in Microbiology, 6, 2015. ISSN 1664-302X. doi: 10.3389/ fmicb.2015.00235.

H. J. Dyson and P. E. Wright. How Do Intrinsically Disordered Viral Proteins Hijack the Cell? Biochemistry, 57(28):4045-4046, July 2018. ISSN 1520-4995 (Electronic) 0006-2960 (Linking). doi: 10.1021/acs.biochem. $8 \mathrm{~b} 00622$

I. Ersing, L. Nobre, L. W. Wang, L. Soday, Y. Ma, J. A. Paulo, Y. Narita, C. W. Ashbaugh, C. Jiang, N. E. Grayson, E. Kieff, S. P. Gygi, M. P. Weekes, and B. E. Gewurz. A Temporal Proteomic Map of Epstein-Barr Virus Lytic Replication in B Cells. Cell Rep, 19(7):1479-1493, May 2017. ISSN 2211-1247 (Electronic). doi: 10.1016/j.celrep.2017.04.062. 
bioRxiv preprint doi: https://doi.org/10.1101/548909; this version posted February 13, 2019. The copyright holder for this preprint (which

was not certified by peer review) is the author/funder. All rights reserved. No reuse allowed without permission.

E. A. Franzosa and Y. Xia. Structural principles within the human-virus protein-protein interaction network. Proc Natl Acad Sci U S A, 108(26):10538-43, June 2011. ISSN 1091-6490 (Electronic) 0027-8424 (Linking). doi: 10.1073/pnas.1101440108.

Qianqian Gao, Shilin Yuan, Chao Zhang, Ying Wang, Yizhuo Wang, Guimei He, Shuyi Zhang, Ralf Altmeyer, and Gang Zou. Discovery of Itraconazole with Broad-Spectrum In Vitro Antienterovirus Activity That Targets Nonstructural Protein 3A. Antimicrobial Agents and Chemotherapy, 59(5):2654-2665, May 2015. ISSN 0066-4804, 1098-6596. doi: 10.1128/AAC.05108-14.

A. Garcia-Sastre. Ten Strategies of Interferon Evasion by Viruses. Cell Host Microbe, 22(2):176-184, August 2017. ISSN 1934-6069 (Electronic) 1931-3128 (Linking). doi: 10.1016/j.chom.2017.07.012.

Sarah E. Hickson, Daciana Margineantu, David M. Hockenbery, Julian A. Simon, and Adam P. Geballe. Inhibition of vaccinia virus replication by nitazoxanide. Virology, 518:398-405, May 2018. ISSN 1096-0341. doi: $10.1016 /$ j.virol.2018.03.023.

A. J. Hirsch. The use of RNAi-based screens to identify host proteins involved in viral replication. Future Microbiol, 5(2):303-11, February 2010. ISSN 1746-0921 (Electronic) 1746-0913 (Linking). doi: 10.2217/ fmb.09.121.

C. R. Howard and N. F. Fletcher. Emerging virus diseases: Can we ever expect the unexpected? Emerg Microbes Infect, 1(12):e46, December 2012. ISSN 2222-1751 (Print) 2222-1751 (Linking). doi: 10.1038/emi. 2012.47 .

W. Huang da, B. T. Sherman, and R. A. Lempicki. Systematic and integrative analysis of large gene lists using DAVID bioinformatics resources. Nat Protoc, 4(1):44-57, 2009. ISSN 1750-2799 (Electronic) 1750-2799 (Linking). doi: 10.1038/nprot.2008.211.

A. Ianevski, E. Zusinaite, S. Kuivanen, M. Strand, H. Lysvand, M. Teppor, L. Kakkola, H. Paavilainen, M. Laajala, H. Kallio-Kokko, M. Valkonen, A. Kantele, K. Telling, I. Lutsar, P. Letjuka, N. Metelitsa, V. Oksenych, M. Bjoras, S. A. Nordbo, U. Dumpis, A. Vitkauskiene, C. Ohrmalm, K. Bondeson, A. Bergqvist, T. Aittokallio, R. J. Cox, M. Evander, V. Hukkanen, V. Marjomaki, I. Julkunen, O. Vapalahti, T. Tenson, A. Merits, and D. Kainov. Novel activities of safe-in-human broad-spectrum antiviral agents. Antiviral Res, 154: 174-182, June 2018. ISSN 1872-9096 (Electronic) 0166-3542 (Linking). doi: 10.1016/j.antiviral.2018.04.016.

K. K. Irwin, N. Renzette, T. F. Kowalik, and J. D. Jensen. Antiviral drug resistance as an adaptive process. Virus Evol, 2(1):vew014, January 2016. ISSN 2057-1577 (Print) 2057-1577 (Linking). doi: 10.1093/ve/ vew014.

Stefanie Jäger, Peter Cimermancic, Natali Gulbahce, Jeffrey R. Johnson, Kathryn E. McGovern, Starlynn C. Clarke, Michael Shales, Gaelle Mercenne, Lars Pache, Kathy Li, Hilda Hernandez, Gwendolyn M. Jang, Shoshannah L. Roth, Eyal Akiva, John Marlett, Melanie Stephens, Iván D'Orso, Jason Fernandes, Marie Fahey, Cathal Mahon, Anthony J. O’Donoghue, Aleksandar Todorovic, John H. Morris, David A. Maltby, Tom Alber, Gerard Cagney, Frederic D. Bushman, John A. Young, Sumit K. Chanda, Wesley I. Sundquist, Tanja Kortemme, Ryan D. Hernandez, Charles S. Craik, Alma Burlingame, Andrej Sali, Alan D. Frankel, and Nevan J. Krogan. Global landscape of HIV-human protein complexes. Nature, 481(7381):365-370, December 2011. ISSN 1476-4687. doi: 10.1038/nature10719.

R. K. Kandasamy, G. I. Vladimer, B. Snijder, A. C. Muller, M. Rebsamen, J. W. Bigenzahn, A. Moskovskich, M. Sabler, A. Stefanovic, S. Scorzoni, M. Bruckner, T. Penz, C. Cleary, R. Kralovics, J. Colinge, K. L. Bennett, and G. Superti-Furga. A time-resolved molecular map of the macrophage response to VSV infection. NPJ Syst Biol Appl, 2:16027, 2016. ISSN 2056-7189 (Print) 2056-7189 (Linking). doi: 10.1038/npjsba.2016. 27.

S. H. E. Kaufmann, A. Dorhoi, R. S. Hotchkiss, and R. Bartenschlager. Host-directed therapies for bacterial and viral infections. Nat Rev Drug Discov, 17(1):35-56, January 2018. ISSN 1474-1784 (Electronic) 14741776 (Linking). doi: 10.1038/nrd.2017.162.

Sudip Khadka, Abbey D. Vangeloff, Chaoying Zhang, Prasad Siddavatam, Nicholas S. Heaton, Ling Wang, Ranjan Sengupta, Sudhir Sahasrabudhe, Glenn Randall, Michael Gribskov, Richard J. Kuhn, Rushika Perera, and Douglas J. LaCount. A physical interaction network of dengue virus and human proteins. Molecular \&s cellular proteomics: MCP, 10(12):M111.012187, December 2011. ISSN 1535-9484. doi: 10. 1074/mcp.M111.012187.

H. Y. Kim, S. Kong, S. Oh, J. Yang, E. Jo, Y. Ko, S. H. Kim, J. Y. Hwang, R. Song, and M. P. Windisch. Benzothiazepinecarboxamides: Novel hepatitis $\mathrm{C}$ virus inhibitors that interfere with viral entry and the generation of infectious virions. Antiviral Res, 129:39-46, May 2016. ISSN 1872-9096 (Electronic) 01663542 (Linking). doi: 10.1016/j.antiviral.2016.01.010. 
bioRxiv preprint doi: https://doi.org/10.1101/548909; this version posted February 13, 2019. The copyright holder for this preprint (which

was not certified by peer review) is the author/funder. All rights reserved. No reuse allowed without permission.

Y. Kondo, K. Machida, H. M. Liu, Y. Ueno, K. Kobayashi, T. Wakita, T. Shimosegawa, and M. M. Lai. Hepatitis $\mathrm{C}$ virus infection of $\mathrm{T}$ cells inhibits proliferation and enhances fas-mediated apoptosis by downregulating the expression of CD44 splicing variant 6. J Infect Dis, 199(5):726-36, March 2009. ISSN 0022-1899 (Print) 0022-1899 (Linking). doi: 10.1086/596739.

R. Konig, S. Stertz, Y. Zhou, A. Inoue, H. H. Hoffmann, S. Bhattacharyya, J. G. Alamares, D. M. Tscherne, M. B. Ortigoza, Y. Liang, Q. Gao, S. E. Andrews, S. Bandyopadhyay, P. De Jesus, B. P. Tu, L. Pache, C. Shih, A. Orth, G. Bonamy, L. Miraglia, T. Ideker, A. Garcia-Sastre, J. A. Young, P. Palese, M. L. Shaw, and S. K. Chanda. Human host factors required for influenza virus replication. Nature, 463(7282):813-7, February 2010. ISSN 1476-4687 (Electronic) 0028-0836 (Linking). doi: 10.1038/nature08699.

Yen-Chung Lai, Yung-Chun Chuang, Chih-Peng Chang, Yee-Shin Lin, Guey-Chuen Perng, Han-Chung Wu, Shie-Liang Hsieh, and Trai-Ming Yeh. Minocycline suppresses dengue virus replication by down-regulation of macrophage migration inhibitory factor-induced autophagy. Antiviral Research, 155:28-38, July 2018. ISSN 1872-9096. doi: 10.1016/j.antiviral.2018.05.002.

Stefan Langhammer, Robert Koban, Constanze Yue, and Heinz Ellerbrok. Inhibition of poxvirus spreading by the anti-tumor drug Gefitinib (Iressa). Antiviral Research, 89(1):64-70, January 2011. ISSN 1872-9096. doi: $10.1016 /$ j.antiviral.2010.11.006.

M. A. Larkin, G. Blackshields, N. P. Brown, R. Chenna, P. A. McGettigan, H. McWilliam, F. Valentin, I. M. Wallace, A. Wilm, R. Lopez, J. D. Thompson, T. J. Gibson, and D. G. Higgins. Clustal W and Clustal $\mathrm{X}$ version 2.0. Bioinformatics, 23(21):2947-8, November 2007. ISSN 1367-4811 (Electronic) 1367-4803 (Linking). doi: 10.1093/bioinformatics/btm404.

M. C. Lee, E. A. Miller, J. Goldberg, L. Orci, and R. Schekman. Bi-directional protein transport between the ER and Golgi. Annu Rev Cell Dev Biol, 20:87-123, 2004. ISSN 1081-0706 (Print) 1081-0706 (Linking). doi: 10.1146/annurev.cellbio.20.010403.105307.

M. Mancek-Keber, M. Bencina, B. Japelj, G. Panter, J. Andra, K. Brandenburg, M. Triantafilou, K. Triantafilou, and R. Jerala. MARCKS as a negative regulator of lipopolysaccharide signaling. J Immunol, 188(8): 3893-902, April 2012. ISSN 1550-6606 (Electronic) 0022-1767 (Linking). doi: 10.4049/jimmunol.1003605.

I. Marazzi, J. S. Ho, J. Kim, B. Manicassamy, S. Dewell, R. A. Albrecht, C. W. Seibert, U. Schaefer, K. L. Jeffrey, R. K. Prinjha, K. Lee, A. Garcia-Sastre, R. G. Roeder, and A. Tarakhovsky. Suppression of the antiviral response by an influenza histone mimic. Nature, 483(7390):428-33, March 2012. ISSN 1476-4687 (Electronic) 0028-0836 (Linking). doi: 10.1038/nature10892.

C. D. Marceau, A. S. Puschnik, K. Majzoub, Y. S. Ooi, S. M. Brewer, G. Fuchs, K. Swaminathan, M. A. Mata, J. E. Elias, P. Sarnow, and J. E. Carette. Genetic dissection of Flaviviridae host factors through genome-scale CRISPR screens. Nature, 535(7610):159-63, July 2016. ISSN 1476-4687 (Electronic) 0028-0836 (Linking). doi: 10.1038/nature18631.

Jason Mercer, Berend Snijder, Raphael Sacher, Christine Burkard, Christopher Karl Ernst Bleck, Henning Stahlberg, Lucas Pelkmans, and Ari Helenius. RNAi Screening Reveals Proteasome- and Cullin3-Dependent Stages in Vaccinia Virus Infection. Cell Reports, 2(4):1036-1047, October 2012. ISSN 2211-1247. doi: 10.1016/j.celrep.2012.09.003.

B. Meszaros, G. Erdos, and Z. Dosztanyi. IUPred2A: Context-dependent prediction of protein disorder as a function of redox state and protein binding. Nucleic Acids Res, 46(W1):W329-W337, July 2018. ISSN 1362-4962 (Electronic) 0305-1048 (Linking). doi: 10.1093/nar/gky384.

Martin Michaelis, Malte Christian Kleinschmidt, Hans Wilhelm Doerr, and Jindrich Cinatl. Minocycline inhibits West Nile virus replication and apoptosis in human neuronal cells. The Journal of Antimicrobial Chemotherapy, 60(5):981-986, November 2007. ISSN 0305-7453. doi: 10.1093/jac/dkm307.

V. Navratil, B. de Chassey, C. R. Combe, and V. Lotteau. When the human viral infectome and diseasome networks collide: Towards a systems biology platform for the aetiology of human diseases. BMC Syst Biol, 5:13, January 2011. ISSN 1752-0509 (Electronic) 1752-0509 (Linking). doi: 10.1186/1752-0509-5-13.

K. Nightingale, K. M. Lin, B. J. Ravenhill, C. Davies, L. Nobre, C. A. Fielding, E. Ruckova, A. FletcherEtherington, L. Soday, H. Nichols, D. Sugrue, E. C. Y. Wang, P. Moreno, Y. Umrania, E. L. Huttlin, R. Antrobus, A. J. Davison, G. W. G. Wilkinson, R. J. Stanton, P. Tomasec, and M. P. Weekes. HighDefinition Analysis of Host Protein Stability during Human Cytomegalovirus Infection Reveals Antiviral Factors and Viral Evasion Mechanisms. Cell Host Microbe, 24(3):447-460 e11, September 2018. ISSN 1934-6069 (Electronic) 1931-3128 (Linking). doi: 10.1016/j.chom.2018.07.011. 
bioRxiv preprint doi: https://doi.org/10.1101/548909; this version posted February 13, 2019. The copyright holder for this preprint (which

was not certified by peer review) is the author/funder. All rights reserved. No reuse allowed without permission.

C. J. Oldfield and A. K. Dunker. Intrinsically disordered proteins and intrinsically disordered protein regions. Annu Rev Biochem, 83:553-84, 2014. ISSN 1545-4509 (Electronic) 0066-4154 (Linking). doi: 10.1146/ annurev-biochem-072711-164947.

W. C. Olson and J. M. Jacobson. CCR5 monoclonal antibodies for HIV-1 therapy. Curr Opin HIV AIDS, 4(2):104-11, March 2009. ISSN 1746-6318 (Electronic) 1746-630X (Linking). doi: 10.1097/COH. 0b013e3283224015.

C. Patzina, C. H. Botting, A. Garcia-Sastre, R. E. Randall, and B. G. Hale. Human interactome of the influenza B virus NS1 protein. J Gen Virol, 98(9):2267-2273, September 2017. ISSN 1465-2099 (Electronic) 0022-1317 (Linking). doi: 10.1099/jgv.0.000909.

Matthew D. Pauly and Adam S. Lauring. Effective lethal mutagenesis of influenza virus by three nucleoside analogs. Journal of Virology, 89(7):3584-3597, April 2015. ISSN 1098-5514. doi: 10.1128/JVI.03483-14.

K. M. Peck and A. S. Lauring. Complexities of Viral Mutation Rates. J Virol, 92(14), July 2018. ISSN 1098-5514 (Electronic) 0022-538X (Linking). doi: 10.1128/JVI.01031-17.

Ludmila Perelygina, Timo Hautala, Mikko Seppänen, Adebola Adebayo, Kathleen E. Sullivan, and Joseph Icenogle. Inhibition of rubella virus replication by the broad-spectrum drug nitazoxanide in cell culture and in a patient with a primary immune deficiency. Antiviral Research, 147:58-66, November 2017. ISSN 1872-9096. doi: 10.1016/j.antiviral.2017.09.019.

Andreas Pichlmair, Kumaran Kandasamy, Gualtiero Alvisi, Orla Mulhern, Roberto Sacco, Matthias Habjan, Marco Binder, Adrijana Stefanovic, Carol-Ann Eberle, Adriana Goncalves, Tilmann Bürckstümmer, André C. Müller, Astrid Fauster, Cathleen Holze, Kristina Lindsten, Stephen Goodbourn, Georg Kochs, Friedemann Weber, Ralf Bartenschlager, Andrew G. Bowie, Keiryn L. Bennett, Jacques Colinge, and Giulio Superti-Furga. Viral immune modulators perturb the human molecular network by common and unique strategies. Nature, 487(7408):486-490, July 2012. ISSN 0028-0836. doi: 10.1038/nature11289.

Parmjeet S. Randhawa, Noush A. Farasati, Yuchen Huang, Markus Y. Mapara, and Ron Shapiro. Viral Drug Sensitivity Testing Using Quantitative PCR Effect of Tyrosine Kinase Inhibitors on Polyomavirus BK Replication. American journal of clinical pathology, 134(6):916-920, December 2010. ISSN 0002-9173. doi: 10.1309/AJCP7JYHJN1PGQVC.

Jonathan M. O. Rawson, Megan E. Roth, Jiashu Xie, Michele B. Daly, Christine L. Clouser, Sean R. Landman, Cavan S. Reilly, Laurent Bonnac, Baek Kim, Steven E. Patterson, and Louis M. Mansky. Synergistic reduction of HIV-1 infectivity by 5-azacytidine and inhibitors of ribonucleotide reductase. Bioorganic $\mathcal{E}$ Medicinal Chemistry, 24(11):2410-2422, January 2016. ISSN 1464-3391. doi: 10.1016/j.bmc.2016.03.052.

Jean-François Rossignol. Nitazoxanide, a new drug candidate for the treatment of Middle East respiratory syndrome coronavirus. Journal of Infection and Public Health, 9(3):227-230, 2016 May-Jun. ISSN 1876035X. doi: 10.1016/j.jiph.2016.04.001.

Orit Rozenblatt-Rosen, Rahul C. Deo, Megha Padi, Guillaume Adelmant, Michael A. Calderwood, Thomas Rolland, Miranda Grace, Amélie Dricot, Manor Askenazi, Maria Tavares, Samuel J. Pevzner, Fieda Abderazzaq, Danielle Byrdsong, Anne-Ruxandra Carvunis, Alyce A. Chen, Jingwei Cheng, Mick Correll, Melissa Duarte, Changyu Fan, Mariet C. Feltkamp, Scott B. Ficarro, Rachel Franchi, Brijesh K. Garg, Natali Gulbahce, Tong Hao, Amy M. Holthaus, Robert James, Anna Korkhin, Larisa Litovchick, Jessica C. Mar, Theodore R. Pak, Sabrina Rabello, Renee Rubio, Yun Shen, Saurav Singh, Jennifer M. Spangle, Murat Tasan, Shelly Wanamaker, James T. Webber, Jennifer Roecklein-Canfield, Eric Johannsen, Albert-László Barabási, Rameen Beroukhim, Elliott Kieff, Michael E. Cusick, David E. Hill, Karl Münger, Jarrod A. Marto, John Quackenbush, Frederick P. Roth, James A. DeCaprio, and Marc Vidal. Interpreting cancer genomes using systematic host network perturbations by tumour virus proteins. Nature, 487(7408):491-495, July 2012. ISSN 1476-4687. doi: 10.1038/nature11288.

R. Sanjuan and P. Domingo-Calap. Mechanisms of viral mutation. Cell Mol Life Sci, 73(23):4433-4448, December 2016. ISSN 1420-9071 (Electronic) 1420-682X (Linking). doi: 10.1007/s00018-016-2299-6.

Mark Schleiss, Jan Eickhoff, Sabrina Auerochs, Martina Leis, Silke Abele, Sabine Rechter, Yeon Choi, Jodi Anderson, Gillian Scott, William Rawlinson, Detlef Michel, Stephan Ensminger, Bert Klebl, Thomas Stamminger, and Manfred Marschall. Protein kinase inhibitors of the quinazoline class exert anticytomegaloviral activity in vitro and in vivo. Antiviral Research, 79(1):49-61, July 2008. ISSN 0166-3542. doi: $10.1016 /$ j.antiviral.2008.01.154.

Esther E. Schmidt, Oliver Pelz, Svetlana Buhlmann, Grainne Kerr, Thomas Horn, and Michael Boutros. GenomeRNAi: A database for cell-based and in vivo RNAi phenotypes, 2013 update. Nucleic Acids Research, 41(Database issue):D1021-1026, January 2013. ISSN 1362-4962. doi: 10.1093/nar/gks1170. 
Priya S. Shah, Nichole Link, Gwendolyn M. Jang, Phillip P. Sharp, Tongtong Zhu, Danielle L. Swaney, Jeffrey R. Johnson, John Von Dollen, Holly R. Ramage, Laura Satkamp, Billy Newton, Ruth Hüttenhain, Marine J. Petit, Tierney Baum, Amanda Everitt, Orly Laufman, Michel Tassetto, Michael Shales, Erica Stevenson, Gabriel N. Iglesias, Leila Shokat, Shashank Tripathi, Vinod Balasubramaniam, Laurence G. Webb, Sebastian Aguirre, A. Jeremy Willsey, Adolfo Garcia-Sastre, Katherine S. Pollard, Sara Cherry, Andrea V. Gamarnik, Ivan Marazzi, Jack Taunton, Ana Fernandez-Sesma, Hugo J. Bellen, Raul Andino, and Nevan J. Krogan. Comparative Flavivirus-Host Protein Interaction Mapping Reveals Mechanisms of Dengue and Zika Virus Pathogenesis. Cell, 175(7):1931-1945.e18, December 2018. ISSN 0092-8674, 10974172. doi: 10.1016/j.cell.2018.11.028.

Paul Shannon, Andrew Markiel, Owen Ozier, Nitin S. Baliga, Jonathan T. Wang, Daniel Ramage, Nada Amin, Benno Schwikowski, and Trey Ideker. Cytoscape: A software environment for integrated models of biomolecular interaction networks. Genome Research, 13(11):2498-2504, November 2003. ISSN 1088-9051. doi: $10.1101 /$ gr.1239303.

Sagi D. Shapira, Irit Gat-Viks, Bennett O. V. Shum, Amelie Dricot, Marciela M. de Grace, Liguo Wu, Piyush B. Gupta, Tong Hao, Serena J. Silver, David E. Root, David E. Hill, Aviv Regev, and Nir Hacohen. A physical and regulatory map of host-influenza interactions reveals pathways in H1N1 infection. Cell, 139(7):12551267, December 2009. ISSN 1097-4172. doi: 10.1016/j.cell.2009.12.018.

Aeri Shim, Jae-Hyoung Song, Bo-Eun Kwon, Jeong-Jun Lee, Jae-Hee Ahn, Yeon-Jeong Kim, Ki-Jong Rhee, Sun-Young Chang, Younggil Cha, Yong-Soo Lee, Mi-Na Kweon, Kwi Sung Park, Dong-Eun Kim, Sungchan Cho, Hyun-Jong Cho, and Hyun-Jeong Ko. Therapeutic and prophylactic activity of itraconazole against human rhinovirus infection in a murine model. Scientific Reports, 6, March 2016. ISSN 2045-2322. doi: $10.1038 /$ srep23110.

Jennifer A. Smith, Elizabeth A. White, Mathew E. Sowa, Maria L. C. Powell, Matthias Ottinger, J. Wade Harper, and Peter M. Howley. Genome-wide siRNA screen identifies SMCX, EP400, and Brd4 as E2dependent regulators of human papillomavirus oncogene expression. Proceedings of the National Academy of Sciences of the United States of America, 107(8):3752-3757, February 2010. ISSN 1091-6490. doi: 10.1073/pnas.0914818107.

B. Snijder, R. Sacher, P. Ramo, P. Liberali, K. Mench, N. Wolfrum, L. Burleigh, C. C. Scott, M. H. Verheije, J. Mercer, S. Moese, T. Heger, K. Theusner, A. Jurgeit, D. Lamparter, G. Balistreri, M. Schelhaas, C. A. De Haan, V. Marjomaki, T. Hyypia, P. J. Rottier, B. Sodeik, M. Marsh, J. Gruenberg, A. Amara, U. Greber, A. Helenius, and L. Pelkmans. Single-cell analysis of population context advances RNAi screening at multiple levels. Mol Syst Biol, 8:579, April 2012. ISSN 1744-4292 (Electronic) 1744-4292 (Linking). doi: $10.1038 / \mathrm{msb} .2012 .9$

Sandra Söderholm, Yu Fu, Lana Gaelings, Sergey Belanov, Laxman Yetukuri, Mikhail Berlinkov, Anton V. Cheltsov, Simon Anders, Tero Aittokallio, Tuula A. Nyman, Sampsa Matikainen, and Denis E. Kainov. Multi-Omics Studies towards Novel Modulators of Influenza A Virus-Host Interaction. Viruses, 8(10):269, October 2016. doi: 10.3390/v8100269.

Chris Stark, Bobby-Joe Breitkreutz, Teresa Reguly, Lorrie Boucher, Ashton Breitkreutz, and Mike Tyers. BioGRID: A general repository for interaction datasets. Nucleic Acids Research, 34(Database issue):D535D539, January 2006. ISSN 0305-1048. doi: 10.1093/nar/gkj109.

E. Sun, J. He, and X. Zhuang. Dissecting the role of COPI complexes in influenza virus infection. J Virol, 87 (5):2673-85, March 2013. ISSN 1098-5514 (Electronic) 0022-538X (Linking). doi: 10.1128/JVI.02277-12.

Andrew W. Tai, Yair Benita, Lee F. Peng, Sun-Suk Kim, Naoya Sakamoto, Ramnik J. Xavier, and Raymond T. Chung. A functional genomic screen identifies cellular cofactors of hepatitis $\mathrm{C}$ virus replication. Cell Host Es Microbe, 5(3):298-307, March 2009. ISSN 1934-6069. doi: 10.1016/j.chom.2009.02.001.

E. R. Tamarozzi and S. Giuliatti. Understanding the Role of Intrinsic Disorder of Viral Proteins in the Oncogenicity of Different Types of HPV. Int J Mol Sci, 19(1), January 2018. ISSN 1422-0067 (Electronic) 1422-0067 (Linking). doi: 10.3390/ijms19010198.

B. Thaa, K. P. Hofmann, and M. Veit. Viruses as vesicular carriers of the viral genome: A functional module perspective. Biochim Biophys Acta, 1803(4):507-19, April 2010. ISSN 0006-3002 (Print) 0006-3002 (Linking). doi: 10.1016/j.bbamcr.2010.01.011.

S. Tripathi, M. O. Pohl, Y. Zhou, A. Rodriguez-Frandsen, G. Wang, D. A. Stein, H. M. Moulton, P. DeJesus, J. Che, L. C. Mulder, E. Yanguez, D. Andenmatten, L. Pache, B. Manicassamy, R. A. Albrecht, M. G. Gonzalez, Q. Nguyen, A. Brass, S. Elledge, M. White, S. Shapira, N. Hacohen, A. Karlas, T. F. Meyer, M. Shales, A. Gatorano, J. R. Johnson, G. Jang, T. Johnson, E. Verschueren, D. Sanders, N. Krogan, M. Shaw, R. Konig, S. Stertz, A. Garcia-Sastre, and S. K. Chanda. Meta- and Orthogonal Integration of 
bioRxiv preprint doi: https://doi.org/10.1101/548909; this version posted February 13, 2019. The copyright holder for this preprint (which

was not certified by peer review) is the author/funder. All rights reserved. No reuse allowed without permission.

Influenza "OMICs" Data Defines a Role for UBR4 in Virus Budding. Cell Host Microbe, 18(6):723-35, December 2015. ISSN 1934-6069 (Electronic) 1931-3128 (Linking). doi: 10.1016/j.chom.2015.11.002.

Rachel Ulferts, S. Matthijn de Boer, Lonneke van der Linden, Lisa Bauer, Hey Rhyoung Lyoo, Maria J. Maté, Julie Lichière, Bruno Canard, Daphne Lelieveld, Wienand Omta, David Egan, Bruno Coutard, and Frank J. M. van Kuppeveld. Screening of a Library of FDA-Approved Drugs Identifies Several Enterovirus Replication Inhibitors That Target Viral Protein 2C. Antimicrobial Agents and Chemotherapy, 60(5):26272638, April 2016. ISSN 0066-4804. doi: 10.1128/AAC.02182-15.

M. Vidal, M. E. Cusick, and A. L. Barabasi. Interactome networks and human disease. Cell, 144(6):986-98, March 2011. ISSN 1097-4172 (Electronic) 0092-8674 (Linking). doi: 10.1016/j.cell.2011.02.016.

H. W. Virgin, E. J. Wherry, and R. Ahmed. Redefining chronic viral infection. Cell, 138(1):30-50, July 2009. ISSN 1097-4172 (Electronic) 0092-8674 (Linking). doi: 10.1016/j.cell.2009.06.036.

M. P. Weekes, P. Tomasec, E. L. Huttlin, C. A. Fielding, D. Nusinow, R. J. Stanton, E. C. Wang, R. Aicheler, I. Murrell, G. W. Wilkinson, P. J. Lehner, and S. P. Gygi. Quantitative temporal viromics: An approach to investigate host-pathogen interaction. Cell, 157(6):1460-72, June 2014. ISSN 1097-4172 (Electronic) 0092-8674 (Linking). doi: 10.1016/j.cell.2014.04.028.

E. J. Wherry and M. Kurachi. Molecular and cellular insights into T cell exhaustion. Nat Rev Immunol, 15 (8):486-99, August 2015. ISSN 1474-1741 (Electronic) 1474-1733 (Linking). doi: 10.1038/nri3862.

J. A. Wojcechowskyj, C. A. Didigu, J. Y. Lee, N. F. Parrish, R. Sinha, B. H. Hahn, F. D. Bushman, S. T. Jensen, S. H. Seeholzer, and R. W. Doms. Quantitative phosphoproteomics reveals extensive cellular reprogramming during HIV-1 entry. Cell Host Microbe, 13(5):613-623, May 2013. ISSN 1934-6069 (Electronic) 1931-3128 (Linking). doi: 10.1016/j.chom.2013.04.011.

B. Xue, D. Blocquel, J. Habchi, A. V. Uversky, L. Kurgan, V. N. Uversky, and S. Longhi. Structural disorder in viral proteins. Chem Rev, 114(13):6880-911, July 2014. ISSN 1520-6890 (Electronic) 0009-2665 (Linking). doi: $10.1021 / \mathrm{cr} 4005692$.

Leiliang Zhang, Nancy Y. Villa, Masmudur M. Rahman, Sherin Smallwood, Donna Shattuck, Chris Neff, Max Dufford, Jerry S. Lanchbury, Joshua Labaer, and Grant McFadden. Analysis of vaccinia virus-host protein-protein interactions: Validations of yeast two-hybrid screenings. Journal of Proteome Research, 8 (9):4311-4318, September 2009. ISSN 1535-3893. doi: 10.1021/pr900491n.

R. Zhang, J. J. Miner, M. J. Gorman, K. Rausch, H. Ramage, J. P. White, A. Zuiani, P. Zhang, E. Fernandez, Q. Zhang, K. A. Dowd, T. C. Pierson, S. Cherry, and M. S. Diamond. A CRISPR screen defines a signal peptide processing pathway required by flaviviruses. Nature, 535(7610):164-8, July 2016. ISSN 1476-4687 (Electronic) 0028-0836 (Linking). doi: 10.1038/nature18625.

Nan Zhou, Ting Pan, Junsong Zhang, Qianwen Li, Xue Zhang, Chuan Bai, Feng Huang, Tao Peng, Jianhua Zhang, Chao Liu, Liang Tao, and Hui Zhang. Glycopeptide Antibiotics Potently Inhibit Cathepsin L in the Late Endosome/Lysosome and Block the Entry of Ebola Virus, Middle East Respiratory Syndrome Coronavirus (MERS-CoV), and Severe Acute Respiratory Syndrome Coronavirus (SARS-CoV). The Journal of Biological Chemistry, 291(17):9218-9232, April 2016. ISSN 1083-351X. doi: 10.1074/jbc.M116.716100.

A. Zumla, M. Rao, R. S. Wallis, S. H. Kaufmann, R. Rustomjee, P. Mwaba, C. Vilaplana, D. Yeboah-Manu, J. Chakaya, G. Ippolito, E. Azhar, M. Hoelscher, M. Maeurer, and consortium Host-Directed Therapies Network. Host-directed therapies for infectious diseases: Current status, recent progress, and future prospects. Lancet Infect Dis, 16(4):e47-63, April 2016. ISSN 1474-4457 (Electronic) 1473-3099 (Linking). doi: 10.1016/S1473-3099(16)00078-5. 